\title{
A jódmentes szintetikus amiodaron-kongéner dronedaron odüsszeája: az antiaritmiás gyógyszerfejlesztés szürke fejezete
}

\author{
Fazekas Tamás
}

Szegedi Tudományegyetem, Szent-Györgyi Albert Klinikai Központ, Általános Orvostudományi Kar, I. Belgyógyászati Klinika, Szeged

Levelezési cím: Dr. Fazekas Tamás, 6720 Szeged, Oroszlán u. 4. E-mail: fazekas.tamas@med.u-szeged.hu

„we are still on the quest to find a good, effective and safe antiarrhythmic..." (Gregory YH Lip)

„mindig lehetetlennek tünik, mielőtt megcsinálod” (Nelson Mandela)

A dolgozatot a 80 éves Papp Gyula akadémikusnak ajánlom.

A dronedaron új, jódmentes szintetikus benzofurán-származék, amelyet azzal a céllal fejlesztettek ki, hogy kiiktassák a leghatásosabb és leggyakrabban alkalmazott antiaritmiás gyógyszer, az amiodaron nemkívánatos extrakardiális hatásait. A dronedaron az amiodaronhoz hasonló elektrofarmakológiai hatásspektrummal bíró „multichannel” gátló gyógyszer. Több prospektív véletlen beválasztású, placebo-kontrollcsoportos klinikai vizsgálat (DAFNE, EURIDIS/ADONIS, ERATO, ATHENA) azt sugallta, hogy a dronedaron ( $800 \mathrm{mg} / \mathrm{die})$ hatásos és biztonságos gyógyszer, amely a sinusritmus megtartására és a pitvarfibrilláció kamrafrekvencia-csökkentő/ellenőrző terápiájára egyaránt alkalmas. Ezzel szemben, az ANDROMEDA- és PALLAS-tanulmányok bizonyították, hogy szisztolés/kongesztív szívelégtelenségben (CHF) és károsodott balkamra-funkciójú betegekben (LVEF $\leq 35 \%$; NYHA III-IV.) a dronedaron megkettőzi a halálozást. A dronedaron második- vagy harmadik vonalbeli gyógyszerként alkalmazható kis szív-érrendszeri (CV=kardiovaszkuláris) kockázattal bíró, normális vagy alig károsodott kamrafunkciójú, szimptómás, intermittálóan pitvarfibrilláló betegek sinusritmusának megőrzése végett. Dacára annak, hogy a dronedaron jódmentes vegyület, egyrészt tüdőtoxikus, másrészt csak szervátültetéssel menthető májelégtelenséget okozhat. A dronedaron ellenjavalt CHF-ben, valamint rossz balkamra-funkciójú és permanens pitvarfibrilláló betegekben. A dronedaron helye a pitvarfibrilláció kezelésében egyelöre nem határozható meg pontosan, és háboríthatatlanul minősíthető „szürkének”, kielégítő hatásosság és biztonságosság híján. „A dronedaron-szcenárió arra példa, hogy a kezdeti lelkesedés nagyobb, mint a szisztematikus munkával összegyűjtött bizonyítékokon nyugvó valóság. Jelenleg ott tartunk, küzdeni kell, hogy találjunk olyan kis CV-kockázatú, pitvarfibrillációban szenvedő beteget, akinél a dronedaron hatásos és biztonságos” mondta Kaul (egy FDA vezető).

Kulcsszavak: antiaritmiás farmakoterápia, pitvarfibrilláció, amiodaron, drponedaron

The Odyssey of the synthetic noniodinated amiodarone congener, dronedarone: a grey chapter of the antiarrhythmic drug development

Dronedarone is a novel synthetic noniodinated benzofuran derivative that has been developed to eliminate the adverse effects of the most effective and commonly used antiarrhythmic drug, amiodarone. Dronedarone's electrophysiological spectrum is largely similar of the "multichannel" inhibitor/multitarget amiodarone. Some prospective, randomized, controlled clinical trials (DAFNE, EURIDIS/ADONIS, ERATO, ATHENA) have suggested safety, sinus rhythm maintaining and/or ventricular rate controlling efficacy of dronedarone ( $800 \mathrm{mg} /$ day). In contrary, ANDROMEDA and PALLAS trials raised safety concerns for patients with systolic/congestive heart failure (CHF) and severe left ventricular dysfunction (LVEF $\leq 35 \%$; NYHA III-IV) by doubling cardiovascular mortality. Dronedarone could be a useful second- or third-line agent for some of the low-risk symptomatic intermittent (paroxysmal/persistent) AF patients requiring rhythm control. Despite the fact that dronedarone does not contain iodine, severe liver injury (requiring urgent liver transplantation) and lung toxicity were reported. Dronedarone should not be used for patients with CHF, those with left ventricular dysfunction (LVEF $\leq 35 \%$ ) and/or permanent AF. Until now, dronedarone's place in the management of AF remains largely undefined and grey, primarily because of its relative lack of efficacy and safety. 'The scenario related to dronedarone is an example of enthusiasm exceeding the evidence and one has to struggle to find a low-risk atrial fibrillation population/patient where it would more effective and not be unsafe", said Kaul, a FDA panel member.

Keywords: antiarrhythmic pharmacotherapy; atrial fibrillation; amiodarone; dronedarone 
A dronedaron az amiodaronéhoz hasonló kémiai szerkezetű antiaritmiás gyógyszer. Jódmentes szintetikus benzofurán-származék, amelyet azzal a céllal fejlesztettek ki, hogy kiiktassák a mindmáig leghatásosabb és leggyakrabban alkalmazott antitachyarrhythmiás gyógyszer, az amiodaron (Cordarone ${ }^{\mathrm{TM}}$ ) nemkívánatos extrakardiális/toxikus hatásait. Elektrofarmakológiai hatásspektruma hasonlít a multichannel (csaknem valamennyi befelé irányuló [depolarizáló] és kifelé áramló (repolarizáló) transsarcolemmalis kationáramot gátló] amiodaronéhoz. A jó kamrafunkcióval (bal kamrai ejekciós frakció=LVEF >45\%) rendelkező, visszatérő/ intermittáló (paroxizmális és/vagy perzisztens) pitvarfibrillációban (atrial fibrillation=AF) szenvedő betegeken korábban végzett, prospektív, internacionális, placebo-kontrollcsoportos vizsgálatok (DAFNE, EURIDIS/ ADONIS, ATHENA, ERATO) eredményei azt sejtették, hogy a per os dronedaron $(2 \times 400 \mathrm{mg} /$ die) terápia a rövidebb-hosszabb ideig fennálló AF-et rohamok/attakok megelőzésének, a sinusritmus megőrzésének (,ritmuskontroll”) és/vagy a pitvarfibrilláció (AF = atrial fibrillation) okozta szapora kamramüködés („kamrafrekvencia-kontroll") csökkentésének és a sok betegnél pánikkeltő palpitáció mérséklésének effektív és klinikailag biztonságos farmakológiai eszköze lesz. A viszonylag rövid idő után félbeszakított nagyobb mintaszámú, randomizált, placebo-kontrollcsoportos ANDROMEDA- és PALLAS-vizsgálatok, és az eladdig 3 végzett klinikai vizsgálatok indirekt metaanalízisei bizonyították, hogy dronedaron pangásos szisztolés szívelégtelenségben ( $\mathrm{CHF}=$ congestive heart failure) szenvedő, rossz balkamra-funkciójú (LVEF $\leq 40 \%$ ) és/vagy permanens/állandósult AF-ben szenvedő pácienseknek nem adható, mert ebben a kohorszban növeli az össz- és szív- és érrendszeri halálozást. Miután a szelektált, viszonylag kicsi kardiovaszkuláris ( $C V=s z i ́ v-$ és érrendszeri) kockázatú betegcsoportokon végzett klinikai farmakológiai vizsgálatok eredményei reménykeltőek voltak, a dronedaron (Multaq ${ }^{\mathrm{TM}}$ ) forgalombahozatalát a Food and Drug Administration (FDA), majd a European Medicines Agency (EMA) 2009-ben engedélyezte. Megkezdődhetett az antiaritmikum széles körü real-world/world-wide alkalmazása, kezdetben csupán öt-hat országban, később világszerte. A kezdeti, sokak szerint megalapozatlan lelkesedés/hype elsősorban a lágy végpontnak (soft surrogate) tartott, CV-okra visszavezethető hospitalizáció számának csökkenését alátámasztó ATHENA-vizsgálat után felerősödő agresszív gyógyszergyári kampány és az AF megelőzésére alkalmas, effektív és mellékhatásmentes antiaritmikum hiánya/szüksége nyomán alakulhatott ki. Az amiodaron és a dronedaron AF-megelőző hatását szemtől szemben (head-to-head) összehasonlító DIONYSOS-vizsgálatot is hamar (hét hónap után) felfüggesztették, mert az amiodaron a posztkardioverziós perzisztens AF megelőzésében sokkal hatásosabbnak bizonyult, mint a dronedaron. A placebo-kontrollcsoportos vizsgálatok eredményeit biostatisztikailag összesítő metaanalízisek azt is bizonyították, hogy az anyavegyület, ti. az amiodaron (az AF-profilaxis tekintetében) az (után)követési időtől függően, kétszer-háromszor effektívebb, mint a jódmentes kongéner. A gyógyszert kongresszusi előadásaikban kitartóan népszerűsítő „véleményformáló” kardiológusok a kétségeket ébresztő eredmények láttán inkább azt hangsúlyozták, hogy a dronedaron AF-megelőző hatásossága/efficacy (az amiodaronhoz viszonyítva) valóban szerény, ellenben nem toxikus és kevés mellékhatása van. A forgalombahozatal után, a posztmarketing időszakban (IV. fázis), amikor a meglehetősen drága (és a társadalombiztosítás által csak néhány országban támogatott) készítmény már csaknem valamennyi európai és tengerentúli országban a gyógyszerpiacra került, egy-két éven belül kiderült, hogy az új antiaritmikum korántsem olyan biztonságos, mint korábban hittük, és nem tesz eleget a gyógyszer-biztonságosság (safety first) (77) újabban érvényes (kétségtelenül egyre szigorúbb, több gyógyszertervező, -gyártó laboratóriumot az antiaritmiás gyógyszerfejlesztés felfüggesztésére kényszerítő) követelményeinek. Májkárosító hatása szerencsére nagyon ritkán jelentkezik, de ha mégis, a beteg életét veszélyeztető heveny májelégtelenség csak sürgős májátültetéssel gyógyítható. Noha a molekula jódmentes, tüdőtoxikus (alveolitis, interstitialis pneumonitis, fibrosis), pajzsmirigymüködés-zavart és immunvasculitist okozó hatása van, s állapotrosszabbodást okozó gyógyszer+gyógyszer-interakcióinak száma is nagy. Nagy CV-kockázatú betegekben QT-intervallumot prolongáló és kamrai proaritmiás aktivitása is van (bigeminiát, torsades de pointes kamrai tachycardiát [VT=ventricular tachycardia] indukálhat). Kizárólag szájon át adható, gasztrointesztinális mellékhatásai azonban gyakoriak és sokfélék (nausea, hányás, erős hasmenés). Az AF megszüntetésére (gyógyszeres kardioverzióra), „orális bolus”-terápiára (a propafenonnal, flekainiddel vagy ranolazinnal ellentétben) alkalmatlan. Nem adható organikus szívbetegség talaján kialakuló ventricularis szívritmuszavarokban, permanens AF-ben, CHF-ben (NYHA III-IV), veseelégtelenségben (kreatinin-clearence $<30 \mathrm{ml} / \mathrm{min}$ ) és terhességben. Ha a kamrai repolarizációs idő (az EKG QT-intervalluma) 500 ms-nál hosszabb és/vagy a dronedaron-kezelés alatt eléri ezen proaritmiával fenyegető határértéket, adagolását a torsades de pointes VT fellépésének rizikója miatt fel kell függeszteni. Az eleddig elvégzett és publikált véletlen beválasztásos, kontrollált klinikai vizsgálatok és metaanalízisek eredményeinek, valamint a forgalombahozatal után világszerte gyüjtött „posztmarketing” klinikai tapasztalatok tükrében leszögezhető, hogy a dronedaron egyfelől az intermittáló AF megelőzésének gyenge gyógyszere, másfelöl (a klinikai kipróbálás kezdeti szakaszában reméltekkel ellentétben) nem is elég biztonságos, úgyhogy kifejlesztése nem hozott a klinikai tachyarrhythmiák terápiájában számottevő előrelépést. Alkalmazása 
az utóbbi években világszerte alábbhagyott, a reálisan indokolt indikációs kör egyre kisebb: ma már a sinusritmus megőrzése végett csupán tüneteket okozó, intermittáló, spontán megszűnésre hajlamos, AF-ben/pitvarlebegésben (AFlu), anatómiailag ép (lone AF/AFlu) vagy minimálisan károsodott szívvel, kicsi CV-kockázattal és normális májmüködéssel bíró betegeknek rendelhető. A European Medicines Agency (EMA) a dronedaron alkalmazását csak akkor tartja (az előbb felsorolt feltételek szem előtt tartásával) indokoltnak, ha minden más egyéb farmakoterápiás/antiaritmiás gyógyszeres próbálkozás sikertelen volt, noha az eddig összegyült klinikai tapasztalok alapján a Multaq ${ }^{\mathrm{TM}}$ ezekben az esetekben is ineffektív. A gyógyszer okozta mérsékelt kreatinin-vérszintemelkedés vesefunkció-romlás látszatát kelti, s arra késztetheti az (egyelöre ártalmatlannak vélt/minősített hatást nem ismerő) orvost, hogy a vesén át kiürülő gyógyszer(ek) (pl. a renalisan eliminálódó ACE-gátló) adagját csökkentse, ami azután (pl. CHFben) állapotrosszabbodást okozhat.

Az antiaritmiás (szívritmuszavar-megelőző és/vagy -megszüntető) gyógyszerek több mint százéves történetének áttekintése után nem tekinthető pesszimisztikusnak a sokszor ismételt megállapítás: we are still on the quest to find a good, effective and safe antiarrhythmic $(3,18,19,21,23,29,35,56,76)$. Vitathatatlan, hogy az antiaritmiás gyógyszertervezés és -fejlesztés nem tudott lépést tartani az utóbbi évtizedekben robbanásszerűen (főképp instrumentálisan) fejlődő intervenciós (techno)kardiológia előrehaladásával (10, 25 , 29, 36, 47, 50, 62). Végleges AF-mentességet nyújtó, tartósan/per os adható, nemkívánatos hatásoktól és gyógyszer + gyógyszer/táplálék-interakcióktól mentes „ideális” antiaritmikummal, noha a gyógyszeripar ilyen irányú szellemi erőfeszítései és financiális befektetése évtizedek óta gigásziak, mind a mai napig nem rendelkezünk $(15,22,28,35,48,57,75,85)$.

A világ valamennyi orvosát megdöbbentették az 1970es évek végén és a 80-as években kifejlesztett antiaritmikumokkal (jobbadán szívinfarktusos betegeken) végzett viszonylag nagy mintaszámú, prospektív, véletlen beválasztásos, placebo-kontrollcsoportos (evidence-based) klinikai tanulmányok eredményei (25, 85). A „paradigmaváltó” CAST (Cardiac Arrhythmia Suppression Trial) bizonyította, hogy a szívizomsejtek depolarizációjáért (a transzmembrán akciós potenciál villámgyors [cca. $1 \mathrm{~ms}-\mathrm{os}$ ] felszálló 0 . fázisáért) felelős rapid $\mathrm{Na}^{+}$-beáramlást és az ingerület tovaterjedését lassító antitachyarrhythmiás gyógyszerek (CAST I: flekainid, enkainid; CAST-II, moricizine/ethmozin) megszüntetik vagy nagymértékben csökkentik a (poszt)infarktusos betegek ventricularis extrasystoliáját (VES), ellenben, mindannyiunk megdöbbenésére, szignifikánsan növelték e betegek halálának relatív kockázatát és gyakoriságát $(25,33,34,82,85)$. A mortalitásnövekedés hátterében, mai tudásunk szerint, elsősorban ezen gyógyszerek kardiodepresszív (a szívizom elekt- romos és/vagy mechanikai működését deprimáló) és/ vagy proaritmiás/profibrilláns (végzetes kamrai tachycardiát $=\mathrm{VT}$-t/kamraremegést $=\mathrm{VF}$-et) előidéző hatása áll(t) $(32,33,48,53,60,77)$. Az experimentális szívelektrofarmakológia és gyógyszerkutatás „bibliája” mind a mai napig a Szekeres László (1921-2012) és Papp Gyula (1937-) által angolul publikált monumentális (448 lapon 1293 cikket földolgozó) monográfia (Experimental cardiac arrhythmias and antiarrhythmic drugs, 1971) (75), amely a kinin/kinidin (Wenckebach, 1914) felfedezésétől és gyógyszerpiacra bocsátásától 1970-ig minden fontos szívritmuszavarra és antiaritmiás vegyületre/gyógyszerre vonatkozó elektrofarmakológiai, patofiziológiai, gyógyszerészi kémiai, in vitro és in vivo állatkísérletes adatot ismertet, beleértve a szegedi munkacsoport már akkor nemzetközi visszhangot kiváltó saját kutatási eredményeit $(19,21,63,80,81)$. A nagyszabású forrásmunka nemzetközi sikere megalapozta a szegedi kardiovaszkuláris (CV) iskola kiválóságainak nagy ívű, világszerte ismert és respektált szakmai-tudományos munkásságát, nemzetközi elismerések, tisztségek és kitüntetések odaítélésével (fém) jelzett életpályáját $(63,80,81)$. Amikor Papp Gyula és tanszéki elődje, a szegedi keringésfarmakológiai iskola tulajdonképpeni megalapítója, Szekeres László meglátogathatták a két szakmateremtő amerikai világnagyság, Brian F. Hoffmann (1925-2013) és Paul Cranefield (1925-2003) kutatólaboratóriumait, örömmel vették tudomásul, hogy (fentebb említett) könyvük ott van az experimentális szív-elektrofiziológia úttörőinek irodai könyvtárában (81). Nyilvánvaló, hogy az idő múlása nem csökkentette az enormis adattömeget és ismeretanyagot tartalmazó, brilliáns monográfia tudományos értékét. Nem volt véletlen, hogy amikor az utóbbi 60-70 év legjelentősebb kardiológusai [Mauricio Rosenbaum (1921-2003), Albrecht Fleckenstein (1917-1992), Benjamin J Scherlag (1932-), Hein JJ Wellens (1935-), Berndt Lüderitz (1940-), Sergie S Barold (1936-), Pedro Brugada (1952-) és mások] e sorok írójáról megtudták, hogy a szegedi egyetem belgyógyász-kardiológusaként munkakapcsolatban volt/van a grandiózus mú szerzőivel, elismerő szavak kíséretében emelték le könyvespolcukról a „Szekeres-Papp-bibliát”; én pedig elnyerhettem a (fölsorolt eminens kardiológusok) jóindulatú támogatását. A szegedi Farmakológiai és Farmakoterápiai Intézet igazgatója (1991-2001), Papp Gyula akadémikus 2002. február 1-i nyugállományba vonulása óta töretlenül folytatja kutató- és oktatómunkáját; azóta az intézetet Varró András (1954-) egyetemi tanár irányítja. Amikor a többek között Széchenyi-, Szent-Györgyi Albert-, Issekutz Béla-, Batthány-Strattmann László-díjjal és Hetényi Géza-emlékéremmel kitüntetett Papp Gyula akadémikus, rendes tag, emeritus profeszszorként átvette az MTA-SZTE Keringésfarmakológiai Kutatócsoportjának vezetését, a folyton folyvást újat kereső, célratörő, sohasem lankadó (nunquam otiosus), a nézeteltéréseket minden élethelyzetben nagystílü- 


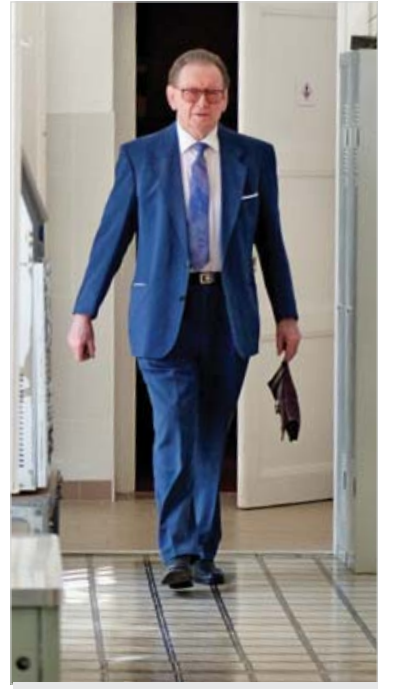

1. ábra. Papp Gyula akadémikus (1939-) 2017 augusztusában, nyolcvanadik születésnapján. A kép az 1980-as évek első felében is készülhetett volna - az ünnepelt testi és szellemi frissessége, megjelenése, határozott járása, stílusa jottányit nem változott en és igazságosan kezelő kutatóprofesszor, megszabadulva az intézetvezetés adminisztratív kötelmeitől, fölvirágoztatta az akadémiai kutatócsoportját munkáját, annak tudományos és publikációs termékenysége tovább erősödött, színesedett (81). A nagy nemzetközi tekintéllyel bíró, mértéktartóan elegáns, rangra és életkorra való tekintet nélkül mindenkivel udvarias akadémikus személyes vonzereje (1. ábra) „méhkaptárként” vonzza a motivált egyetemi hallgatókat, fiatal kutatókat és doktoranduszokat. A 80 . születésnap alkalmából kiadott, a nagyívű életpálya 2002-2017 közötti időszakaszát aprólékosan áttekintő, tartalmilag és könyvészetileg egyaránt pompás, Varró Andrástól és Baczkó Istvántól szerkesztett könyv (81) olvasása közben e sorok íróját (aki Papp Gyulát csaknem 40 éve közelről ismeri) lenyügözte a fiatal kutatókkal, PhD-jelöltekkel való széles körü, felelős oktatói és emberi törődés, az időt sohasem sajnáló kutató- és tanítómunka, amelyet Papp akadémikus (noha ő maga szakmai-tudományos pályája során külföldön és idehaza egyaránt mindent „elért” és megkapott, amit csak lehet), az intézetben munkálkodó doktoranduszoktól sohasem sajnálta az időt, mindig rendelkezésükre állt, amikor Szegeden tartózkodott. Megerősíthetem, hogy ugyanez a gondos tudós-pedagógusi, mentori attitüd jellemezte az akkor még társprofesszor Pappot már az 1980-as évek első felében is, amikor nemritkán "hajnali háromig" velem maradt intézeti irodájában, s értékeltük a vizsgálati eredményeket, „cizelláltuk” kéziratainkat. Viszszaemlékszem, hogy a késő estébe nyúló munka során hamarabb elfáradtam (noha alig múltam 30 éves), mint a negyvenedik életévét átlépő, óriási munkabírású Papp Gyula). Mi sem jellemzőbb ezen dolgozat laureátjára, hogy pár nappal nyolcvanadik születésnapja előtt (2017. augusztus 25-én) kora este is csak munkahelyi dolgozószobájában találtam telefonvégen.

Ez a köszöntő, tisztelgő dolgozat a leghatásosabb, kedvezőtlen mellékhatás spektruma dacára széles körben használt antiaritmiás gyógyszerről, az amiodaronról és kevésbé effektív új, jódmentes származékáról, a dronedaronról szól $(20,55,82,86)$. Már e helyütt leszögezem, hogy Papp Gyula nemzetközileg is úttörő munkát végzett az amiodaron hatásmechanizmusának tisz- tázása területén. Papp 1968-1970 között Edward Miles Vaughan Williams professzorral (1918-2016) Oxfordban végzett (bretyliummal, propranolollal és a hypothyreosis szívhatásaival foglalkozó) munkái és közleményei tankönyvi adatok lettek és fontos részét képezik az antiaritmikumok Vaughan Williams-féle közismert klaszszifikációjának. A szegedi farmakológiai intézet rendkívül sokrétű, félévszázados tudományos munkájából és a már említett komprehenzív monográfiából (75) kiderül, hogy az ún. „analóg-kutatás” nem mindig hozta meg a remélt eredményeket: erre példa a helyi érzéstelenitő prokainból kifejlesztett lidokain $(32,75,76)$. A lidokain intravénásan befecskendezve megszünteti a heveny szívizominfarktus korai kórházi szakaszában fellépő [akkortájt az egyenáramú defibrillációt/kardioverzót kifejlesztő Bernard Lown (1921-) nyomán „figyelmezető/warning” aritmiának nevezett, VT-t/VF-et „előrejelző"] ventricularis extrasystoliát (VES), a nagy mintaszámú vizsgálatok és metaanalízisek azonban bizonyították, hogy kardiodepresszív (bradyarrhythmiát/magas fokú AV-blokkot kiváltó) és/vagy kamrai újraingerlődést (re-entry-t) facilitáló hatása miatt a sokáig „népszerü” (gyakorta prehospitálisan intramuszkulárisan injiciált gyógyszer) növeli a szívinfarktusos betegek halálozását $(32,85)$. Mortalitásnövelő hatást észleltek a per os lidokain-analóg mexiletinnel végzett IMPACT (International Mexiletine and Placebo Antiarrhythmic Coronary Trial) tanulmányban, s csalódást okoztak a per os adagolható lidokain-kongénerek (tokainid, lidoflazin) is. A fluorozott lidokain-származék lidoflazin (Clinium ${ }^{\mathrm{TM}}$ ) jó néhány évig antianginás javallattal hazánkban is forgalomban volt; erős QT-intervallumot megnyújtó és proaritmiás (torsades de pointes VT-t kiváltó) hatásáról angol és német folyóiratokban, valamint az Orvosi Hetilapban az elsők között számoltunk be a hetvenes években. Később a lidoflazin okozta kamrai proaritmiát oly sokan és olyan gyakran észlelték, hogy a gyógyszert világszerte kivonták a forgalomból. A késői egyenirányító $\mathrm{K}^{+}$-áram gyors komponensét $\left(\mathrm{I}_{\mathrm{Kr}}\right)$ szelektíven blokkoló, akciós potenciál időtartamot (action potential duration=APD)/kamrai repolarizációt (QT-intervallumot) prolongáló d-sotalollal (friss és régebbi) heveny szívinfarktusos (el)szenvedő betegeken végzett placebo-kontrollcsoportos SWORD (Survival With Oral D-sotalol) vizsgálatot is viszonylag hamar félbeszakították az antiaritmikummal kezeltek körében észlelt markáns halálozásnövekedés miatt. $A d$-sotalolhoz hasonló hatásmechanizmusú (szelektív $\mathrm{I}_{\mathrm{Kr}}$-blokkoló) dofetilid néhány országban ma is forgalomban van, mivel a nagy mintaszámú (>3000; [poszt]infarktusos és CHF-es betegeket is beválasztó) DIAMOND (Danish Investigations of Arrhythmia and Mortality on Dofetilide Study Group) vizsgálatok összegzésekor nem észleltek összmortalitás-növekedést, ezen keményvégpont nézőpontjából a vizsgálat eredménye neutrális lett (19, 77). A dofetilid mégsem népszerü, sok kardiológustól előírt gyógyszer, mert (a vesefunkcióhoz való dózisil- 
lesztés nehézkessége és) a QT(U)-intervallum-megnyúlás talaján fellépő torsades de pointes VT (folyamatos intrakardiális elektrogram-regisztrálással megerősített) gyakorisága (5-10\%) miatt nem tekinthető biztonságosnak, arról nem szólva, hogy adagolása csak minimum háromnapos kórházi megfigyeléssel (szívritmus-monitorozással és vesefunkció-ellenőrzéssel) kezdődhet $(53,54)$. Nem váltak be azok az antiaritmiás gyógyszerjelöltek sem, amelyek nem csupán az $\mathrm{I}_{\mathrm{Kr}}$-t, hanem a repolarizáció másik fontos „szereplőjének” tekinthető késői egyenirányító $\mathrm{K}^{+}$-áram lassú kinetikájú összetevőjét $\left(I_{\mathrm{Ks}}\right)$ is gátolják (azimilid, GLG-V-13), a kombinált $\mathrm{I}_{\mathrm{Kr}}+\mathrm{I}_{\mathrm{Ks}}$-blokk ugyanis az erős repolarizáció-megnyúlással szimultán rövidtávon is fokozza a kamrai repolarizáció diszperzióját $(26,36,54)$ és a szív proaritmia-hajlamát (34). Papp, Varró és a tölük vezetett szorgos munkacsapatok elegáns kísérletei világelsőként bizonyították, hogy az excesszív repolarizáció-megnyúlás során $\mathrm{I}_{\mathrm{Ks}}$-megnyílás áll elő (ez az ún. „repolarizációs tartalék”), amely „védi” a szívizomsejteket és a kamraizomzatot az extrém akciós potenciál időtartam (APD/ QT) megnyúlástól és az annak talaján fellépő, korai utódepolarizációtól indukált torsades de pointes VT-től $(53,54)$. Az antiaitmiás gyógyszerek adagolására vonatkozó, 30-40 év alatt összegyújtött klinikai tapasztalatok felhívták a figyelmet, hogy a szívizomsejt-membrán kation ( $\mathrm{Na}$ és/vagy $\mathrm{K}$ ) csatornáit blokkoló orvosságok a ritmuszavarban szenvedő betegek 3-20\%-ában, (sokszor a „tüneti/szubjektív javulás [pl. extrasystolementesség „bíztosítása”] ellenére) növelik a szívkamrák aritmiakészségét, az életveszélyes/végzetes kamrai tachyarrhythmiák(VT/VF)és/vagy a CHF fellépésének/ rosszabbodásának kockázatát/gyakoriságát $(8,18,24$, $27,28)$. A post-CAST érában, érthető módon, a korábbiaknál nagyobb hangsúlyt kap a gyógyszerjelöltek potenciális ritmuszavarkeltő és/vagy aritmia-súlyosbodást előidéző effektusainak Preklinikai/experimentális és klinikai tanulmányozása, a hatásosság (efficacy) és a biztonságosság (safety) egyenrangú és elfogulatlan öszszevetése (safety and survival first) $(69,77)$. Számos antiaritmiás céllal megtervezett, szintetizált és állatkísérletes modellekben kipróbált vegyület fejlesztését még a preklinikai szakban leállították, és nem kicsi azoknak a hatóanyagoknak/gyógyszerjelölteknek a száma sem, amelyekről a humán/klinikai (farmakológiai) kipróbálás során vagy már a forgalombahozatal után derült ki (sematilid, almokalant, azimilid, dronedaron), hogy nem biztonságosak. Vannak olyan antiaritmikumok, amelyek a klinikailag számottevő (5-9\%os) torsadogen aktivitás dacára több országban a gyógyszerpiacon maradtak (ilyen pl. a hazánkban nem forgalmazott, kizárólag intravénásan bevihető ibutilid/ Corvert $^{\mathrm{TM}}$, amelynek alkalmazását néhány országban azon megfontolás alapján engedélyezték, hogy nagyon gyorsan eliminálódik az emberi szervezetből (4-5 óra), és az intenzív osztályon befecskendezett gyógyszer okozta torsades de pointes VT iv. magnéziummal vagy elektrokardioverzióval viszonylag könnyen megszüntetgető (36). Néhány régebben előállított antiaritmikumot ma már csak ritkán, speciális javallattal/céllal alkalmazunk (mint pl. a mexiletint hosszú-QT-szindrómában; a kinidint Brugada-szindrómában a kardioverter-defibrillátor [ICD] beültetéséig; az ajmalint az EKG-n „rejtett” Brugada-szindróma fölfedésére, stb.). Az antiaritmiás gyógyszerfejlesztés és klinikai fölhasználás hosszú idő óta tartó viszonylagos sikertelenségének (69) tudható be, hogy az utóbbi évtizedekben az AF és a többi aritmia gyógykezelésének előterébe a rohamosan fejlődő ún. nem gyógyszeres/invazív beavatkozások (implantálható antiaritmiás eszközök, szívütem-szabályzó-, kardioverter-defibrillátor-beültetés, transzkatéteres ablatív eljárások, sebészeti és ún. hibrid [mütéti+katéteres] intervenciók) kerültek (10, 23, 25). Az Európai Kardiológiai Társaság(ESC)ezévibarcelonaikongresszusán előzetesen ismertetett többközpontú, randomizált CASTLE-AF (Catheter Ablation versus Standard conventional Treatment with LEft ventricular dysfunction and Atrial Fibrillation) tanulmányban 179 beteget katéterablációval, 184-et a konvencionális AF-vezérfonal útmutatása(i) szerint gyógyszerrel kezeltek. Mindkét csoport betegei zömében NYHA II. stádiumú CHF-ben szenvedtek és többségük (mindkét kohorszban) amiodaront kapott. A katéterablációs kezelés (3 év után) mérsékelte a teljes és CV-halálozást, s a KaplanMeier-görbe már hat hónap után a CHF-fel okolható kórházi kezelések számának szignifikáns csökkenését jelezte. A CASTLE-AF eredményei bíztatóak, alapos megismerésükre azonban csak az in extenso publikáció megjelenése és alapos tanulmányozása után nyílik lehetőség.

Napjainkban egyöntetű vélekedés, hogy optimális, igen hatásos, aritmiaspecifikus, atoxikus, biztonságos (mellékhatásmentes) gyógyszer híján az antiaritmiás farmakoterápiának csak bizonyos betegcsoportokban van létjogosultsága. Ha a klinikailag elhanyagolható pro(tachy)arrhythmiás aktivitással bíró orvosságok (propafenon, d,I-sotalol és egyéb $\beta$-adrenerg-receptor-blokkolók, nondihidropiridin $\mathrm{Ca}^{2+}$-antagonisták) hatástalanok, az intervenciós/transzkatéteres ablatív beavatkozás(ok)nak ellenjavallata van vagy a tüneteket okozó, intermittáló AF-ben szenvedő beteg az invazív redo beavatkozás(ok) elvégzésébe nem egyezik bele és a jobb életminőséget, nagyobb fizikai teherbírást nyújtó sinusritmust részesíti előnyben, ellenjavallat híján, ultimum refugiumként sor kerülhet az AF-profilaxis jelenleg leghatásosabb gyógyszerének, az amiodaronnak (Cordarone $^{\mathrm{TM}}$ ) adagolására (15, 37, 41, 48, 83). Az amiodaronnak számos és sokféle nemkívánatos és szervtoxikus hatása van, úgyhogy csak a jól együttműködő (rendszeres ellenőrzést vállaló) beteggel való alapos megbeszélés/fölvilágosítás és kölcsönös kockázatvállalás után rendelhető. Ugyanez elmondható a gyakorta (transzkatéteres ablációs kísérletek után is) kiújuló, súlyos tüneteket/panaszokat kiváltó AF-ről, ezeknek a 
betegeknek a száma ugyanis, a módszerek/(katéter) technikák látványos fejlődése dacára ma sem kicsi. Az amiodaron elektrofiziológiai jellemzésével Papp és Varró munkacsoportjai az elmúlt 30 évben sokat foglalkoztak és számos, a gyógyszer új típusú hatásait bemutató könyvfejezetük, publikációjuk jelent meg $(61,62,80$, 82, 83); az amiodaron humán elektropatológiájának és klinikumának ismertetésében e sorok írója is részt vállalt. Az említett írásmúvekben taglalt elektrofarmakológiai és klinikai adatok e cikk olvasói számára jobbadán ismertek, ezért ezt az írást néhány (tőlem érdekesnek vélt) orvostörténeti adat felvázolásával kezdem.

\section{Amiodaron}

A borostyánvirágúak (Apiales) rendjébe, az ernyősvirágúak (Umbelliferae) családjába tartozó Ammi visnaga (fogpiszkálófü) (2. ábra). Iránban, Egyiptomban, és számos mediterrán országban honos gyógynövény (arab neve „Khella”, a francia „herbe aux curedents”) $(1,37)$. A „khella” zsigeri simaizom-görcsoldó hatásáról már az Ebersz-papíruszokban szó esik. A „khella” spazmolitikus aktivitása csaknem teljes mértékben a gyógynövény khellin (C14 H12 O5) tartalmának tudható be (3. ábra). A benzofurán-származék khellin kémiai szerkezetének tisztázása (1932) a kairói Malik érdeme (1). A gyógynövény szárított magvaiból készített főzetet már a régi gyógyászok is alkalmazták, ugyanis észrevették, hogy a decoctum képes a gastrointestinum és a húgyutak görcseinek enyhítésére (43). A Nílus deltájában élő embercsoportokban akkortájt endémiás volt a schistosomiasis és az ahhoz nagyon gyakran társuló urolithiasis. Az antik kor gyógyászai a húgyúti „kólikát" évszázadokon át khellával kezelték (43). Az Ammi Visnaga fözete és tinktúrája már 1934-ben bekerült az Egyiptomi Gyógyszerkönyvbe.

Gleb Vasil'evic Anrep (1891-1955) orosz származású

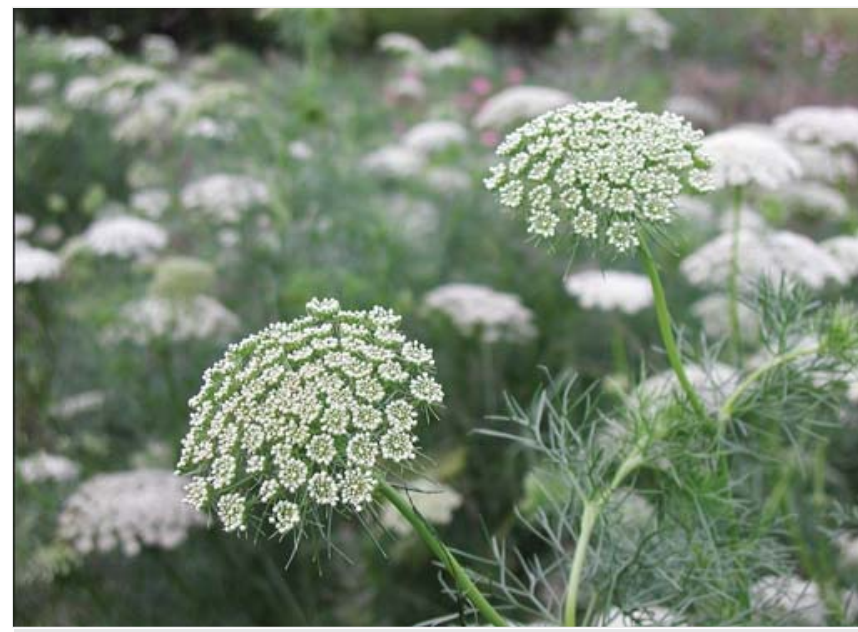

2. ÁBRA. A khellint tartalmazó gyógynövény, az Ammi Visnaga (fogpiszkálófü)<smiles></smiles><smiles>CCc1oc2ccccc2c1C(=O)c1ccc(O)cc1</smiles>

BENZARON<smiles>CCc1oc2ccccc2c1C(=O)c1cc(I)c(O)c(I)c1</smiles><smiles>CCCCc1oc2ccccc2c1C(=O)c1cc(I)c(OCCN(CC)CC)c(I)c1</smiles>

3. ÁBRA. Az amiodaron khellinből izolálható félszintetikus (jódozott) benzofurán-származék

farmakofiziológus, orvosegyetemi tanulmányait Szentpéterváron végezte. A Nobel-díjas orosz élettanász, Ivan Petrovics Pavlov (1849-1936) korán felfigyelt a tehetséges orvostanhallgatóra és 1912-ben tanulmányútra küldte a világhírü Ernest Starling (1866-1927) kutatólaboratóriumába, ahol az ambiciózus medikus elsajátította a Starling-féle szív-tüdő-készítmény öszszeállításának és használatának módszertanát. A poliglott (hat nyelven beszélő) Anrep a cambridge-i egyetem professzora és a Royal Society tagja lett. 1927-ben angolra fordította Pavlov korszakalkotó könyvét (Conditioned reflexes). 1930-ban kinevezték a kairói egyetem élettani/farmakológiai tanszékének élére. A khellin szívre kifejtett jótékony hatásának fölfedezése valójában serendipity-nek (szerencsés, véletlenszerü megfigyelésnek/fölismerésnek) köszönhető. Anrep egyik technikusának erős szívtáji fájdalmakat okozó angina pectorisa és veseköves kólikái voltak, amelyeket a laboratóriumi asszisztens az Egyiptomban már akkor népszerü khellinnel enyhíteni tudott. Tapasztalatait elmondta fönökének, aki ekkor elhatározta, hogy munkatársaival szisztematikusan tanulmányozzák a gyógynövénykivonat szívhatásait $(1,43)$. Kísérleteikben (in situ szív-tüdő-készítményen és alta- 
tott intakt kutyában) kimutatták, hogy a khellin növeli a koronária-vérátáramlást, koszorúér-tágító hatása van. $A z$ antianginás effektust klinikai körülmények között (38 stabil és/vagy nyugalmi/fekvő helyzetben is jelentkező angina pectorisban, valamint nyolc koronária-okklúziót túlélő, posztinfarktusos betegen) is megfigyelték. Nagy hatású publikációjuk 1946-ban jelent meg a British Heart Journal-ben (1). Anrep és munkatársai 1946-i dolgozatában a khellin antitachyarrhythmiás hatásáról még esett szó.

Az Anrep-munkacsapat által megalapozott „khellin-ösvényen" elindulva a Robert Charlier (1935-2014) vezette brilliáns brüsszeli Labaz-kutatócsoport rengeteg benzofurán-származékot állított elő, amelyek közül az egyik (Labaz 3428) különösen hatásosnak bizonyult a különböző állatfajokban aritmogén anyagokkal/beavatkozásokkal (kloroformmal, $\mathrm{CaCl}_{2}$-vel, akonitinnal, acetilkolinnal, koszorúér-ligatúrával, elektromos ingerléssel) előidézett supraventricularis és kamrai aritmiák megszüntetésében és/vagy megelőzésében (7). A Labaz 3428 szintéziséről a belga munkacsoport először 1962-ben számolt be (7). Ez a két jódatomot tartalmazó benzofurán-származék (SR 33589) volt az amiodaron (Cordarone $^{\mathrm{TM}}$ ), amelynek kémiai szerkezetéről viszonylag hamar kiderült, hogy hasonlít a pajzsmirigyhormonokéhoz (a tiroxin/T4 és a trijotironinéhoz/T3) (4. ábra). Az 1960-as évek második felében Charlier megkérte Edward Miles Vaughan Williams-t (1919-2016), az oxfordi Hertford College világhírü farmakológiai laboratóriumának akkori vezetőjét, hogy tárják föl és jellemezzék az amiodaron in vitro elektrofiziológiai tulajdonságait. Vaughan Williams a kísérletek elvégzésével az új-zélandi Otagói Egyetemről érkező Commonwealth Fellow-t, Bramah N Singh-et (1938-2014) bízta meg, aki, experimentális medicinában kevéssé járatos klinikus volt, és az ösztöndíjasként az idő tájt ugyanott dolgozó Papp Gyula segítségével sajátította el az intracelluláris mikroelektród-technika kivitelezésének fortélyait; a magyar kutató segítette Singh-et az erősen lipofil

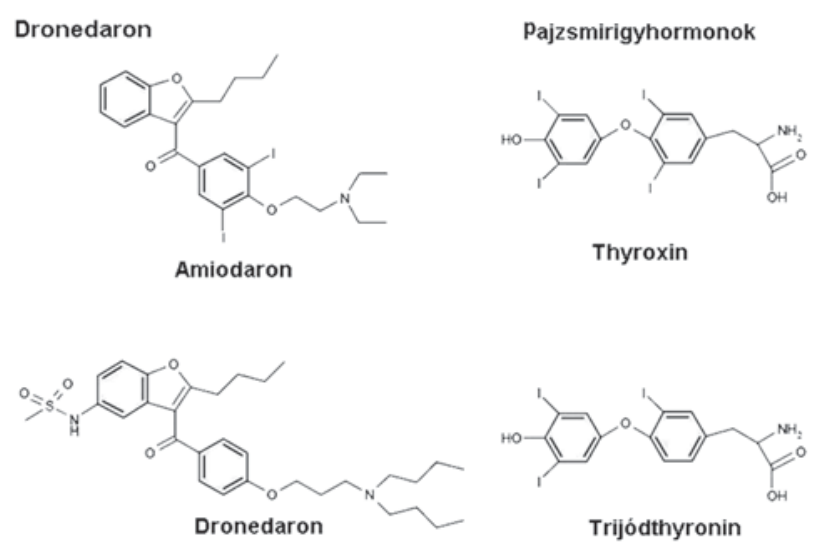

4. ÁBRA. Az amiodaron (bal oldalon, felül) és a dronedaron (bal oldalon, alul) kémiai szerkezete nagyon hasonlít a jobb oldalon látható pajzsmirigyhormonokéhoz benzofurán-származék feloldásának kitalálásában. A két, világhírúvé lett, oxfordi vendégkutató ekkor kötött életre szóló barátságot, amely a kaliforniai/los Angelesi egyetem kardiológus professzorává később kinevezett, az „amiodaron atyjának” titulált Singh elhunytáig tartott (71). Vaughan Williams és Singh alkották meg az antiaritmiás gyógyszerhatások klasszifikációs rendszerét, amely az újabban nagyszámban létező „hibrid” hatásmechanizmusú gyógyszerek kifejlesztése dacára ma is használható kerete az antiaritmiás gyógyszerhatások osztályozásának. Másfelől, „a Vaughan Williams-Singh-Papp" kutatóhármas munkái világossá tették, hogy igenis létezik olyan antiaritmiás/anti-reentry princípium, amelynek lényege a szívizomsejtek akciós potenciál időtartamának/repolarizációjának (APD) és effektív refrakter periódusának (ERP) terápiásan is jól kiaknázható megnyújtása (3. osztályhatás).

Singh (1938-2014) kísérleteit nyúlszívből izolált pitvari és kamrai multicelluláris szívizom-készítményeken végezte (71). Az amiodaron lipofíliája a transzmembrán akciós potenciálok paramétereinek mérését csak hathétig tartó intraperitoneális (ip.) adagolás $(20 \mathrm{mg} /$ ttkg/nap) után lehetett elvégezni. Később kiderült, hogy ez a körülmény a kísérletsorozat szerencsés mozzanata volt, az akut/intravénásan és a krónikusan (tartósan, per os) adagolt amiodaron elektrofiziológiai hatásai ugyanis nagymértékben különbözőek (84). A gyógyszer erőteljesen ( $30 \%)$ megnyújtotta pitvari és kamrai myocardium-készítményekben az akciós potenciál időtartamát (APD) és effektív refrakter periódusát (ERP), anélkül, hogy a nyugalmi membránpotenciált, továbbá az akciós potenciál amplitúdóját (a nyugalmi membránpotenciált) és felszálló szárának meredekségét számottevő mértékben befolyásolta volna $(71,83)$. Fontos megfigyelés volt, hogy az amiodaron (a molekulatömeg 37,2\%-a jód!) APD-ERP-prolongáló hatását tiroxin szimultán ip. adagolásával meg lehetett előzni, ami arra utalt, hogy az antiaritmiás hatás létrejöttében a sarcolemmális pajzsmirigyhormon (T3/T4)-receptorok funkciójának gátlására visszavezethető szignáltranszdukció-inhibíciónak is szerepe lehet, hiszen a T3-gátlás $\mathrm{K}^{+}$-csatorna-downregulációt és csökkent $\beta$-adrenerg-receptor génexpressziót okoz $(62,84)$. A gyógyszer humán kipróbálásában a szívgyógyászat arculatát évtizedeken át meg-határozó világnagyságok, az argentin Mauricio B. Rosenbaum, a kamrai ingerületvezető rendszer trifascikularis szerkezetének felfedezője és Philippe Coumel (1935-2004), a párizsi Lariboisière egyetemi kórház több klinikai entitást és jelenséget (pl. a ma róla elnevezett, Coumel-típusú vagotóniás AF-et) fölfedező igazgató professzora, az aritmiák autonóm idegrendszeri szabályozásának tekintélyes szakértője vállalt úttörő szerepet. Kimutatták, hogy az amiodaronnak emberben is erős antitachyarrhythmiás hatása van. Coumel és munkatársai arra is fölhívták a figyelmet, hogy az amiodaron nem csupán felnőttekben, hanem csecsemő- és gyermekkorban, mi 
több, a foetusban fellépő tachyarrhythmiák kioltására is alkalmas $(23,25)$.

A több mint félévszázada alkalmazott, az összes többi mindmáig kifejlesztett antiaritmikumnál hatásosabb amiodaron másik fő erénye, hogy (monoterápiában, kamrai repolarizációt megnyújtó gyógyszer és/vagy kórállapot híján) nincs klinikailag számottevő proaritmiás (paradox aritmogén) hatása ( torsades de pointes VT-t mindössze a betegek 0,7\%-ában okoz). Az elhanyagolható proaritmiás aktivitás egyik titkát éppen Papp és munkatársai fejtették meg: kimutatták, hogy a hat hétig per os adagolt amiodaron az eredendően hosszabb APD-vel rendelkező Purkinje-rostokban rövidíti, a rövid(ebb) APD-vel rendelkező munkaizomsejteket tartalmazó szívizomrétegekben viszont megnyújtja a kamrai repolarizáció (és az effektív refrakter periódus=ERP) időtartamát, magyarán szólva, a tőle kiváltott APD-prolongáció nem fokozza, hanem mérsékli a myocardium repolarizációjának (fiziológiásan is meglévő, bizonyos kórformákban kifejezett) transmuralis és regionális inhomogenitását (61). Drouin és munkatársai humán bal kamrából kimetszett myocardium-készítmények transmuralis izomrétegeinek (endocardium, epicardium, midmiokardiális M-sejtek) akciós potenciáljait analizálták, s a szegedi munkacsoport kutyaszíven nyert eredményeit megerősítették (22).

Az amiodaronnak (200 mg/die per os) nincs negatív inotrop hatása, ennél fogva pangásos szívelégtelenségben ( $\mathrm{CHF}$ ) szenvedő betegek pitvarfibrillációjának (AF) megelőzésére is alkalmas. A per os amiodaronnal (200 mg/die) az elmúlt évtizedekben több tucat nagy mintaszámú, véletlen beválasztásos, kontrollcsoportos klinikai vizsgálatot végeztek $(20,22,25,48,64,85)$. $E$ tanulmányok és metaanalíziseik rámutattak, hogy a gyógyszer a nagy CV-kockázattal és előrehaladott organikus szívbetegséggel bíró betegcsoportokban sem okoz halálozásnövekedést (85). Rengeteg, különféle betegcsoportokon végzett head-to-head összehasonlító vizsgálat azt is bizonyította, hogy az amiodaron a leghatásosabb AF-megelőző antiaritmikum (22). Szélesebb körű alkalmazásának rendkívül kedvezőtlen extrakardiális mellékhatás-spektruma szab határt (15, 22, 85).

$\mathrm{Az}$ amiodaron hatásosságát az elmúlt negyedszázadban, az ún. „evidence-based” (bizonyíték-alapú) medicina (EBM) korszakában is temérdek nagy elemszámú, randomizált, placebo- vagy aktív kontrollcsoportos vizsgálat és metaanalízis bizonyította. Ezen publikáció (ismertetésétől az amiodaron-analóg dronedaron hányattatására, odüsszeájára fókuszáló dolgozatban eltekintünk $(55,58,66,67,72,87)$. Csupán néhány olyan összehasonlító (amiodaron versus dronedaron) szempontra, vizsgálati eredményre hívom fel a figyelmet, amelyek magyarázzák és/vagy bizonyítják, hogy az újonnan kifejlesztett amiodaron-analóg az intermittáló (paroxizmális és/vagy perzisztens AF) megelőzésének (i.e. a sinusritmus tartós megőrzésének) klinikailag számottevően gyengébb gyógyszere, mint az amiodaron.

Az AF- és az antiaritmiás gyógyszerkutatás kutatás egyik vezéralakja, Stanley Nattel szerkesztőségi cikkében a dronedaronról ír és annak kétarcúságát a skót Stevenson híres regénye főhősének karakteréhez hasonlítja (Strange case of Dr. Jekyll and Mr. Hyde) (5. ábra). Szkeptikusan fogalmaz a kontakt monofázisos akciós potenciál (MAP) technika kifejlesztője, Michael R Franz is, aki dolgozatának címében így kérdez: Amiodarone and dronedarone: the worker bee and the drone? (38). Amiodaron és dronedaron: a méhkaptár dolgozója és a méhkas heréje?). Érdekes véletlen, hogy az

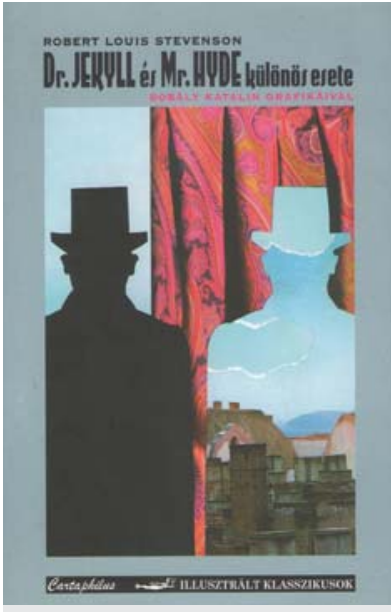

5. ÁBRA. Dr. Jekyll és (Robert Louis Stevenson [1850-1894]). Stanley Nattel, az eminens montreali kardiofarmakológus (a Szegedi Tudományegyetem Díszdoktora) a dronedaront a híres rémregény Janus-arcú föhősével parafrazeálja (58) Mr. Hyde különös esete angol drone szó magyar jelentése „here”. Zimetbaum a dronedaron hányattatását Odüsszeusz tengeri bolyongásához hasonlította (87). James Reiffel, a New York-i Columbia Egyetem vezető kardiológusa így kérdez: Dronedarone for atrial fibrillation: unbridled enthusiasm or just another step forward? (Dronedaron pitvarfibrillációban: zabolátlan lelkesedés vagy éppen egy másik kis előrelépés? (66). Torp-Pedersen, a dán szívgyógyászat legtekintélyesebb klinikusa kijelenti: ....in terms of efficacy, dronedarone is probably not a step forward (77). Az AF kétféle kezelés stratégiáját („sinus-ritmus-megtartás versus kamrafrekvencia-csökkentés/ellenőrzés) először összehasonlító AFFIRM-vizsgálat vezető koordinátora, George D Wyse a dronedaronról szólva egyenesen hype-ról (túlzó felhajtásról, csinnadrattáról) beszél. Nattel, Franz, Zimetbaum, Reiffel, Wyse és a többiek kétségeit a klinikai vizsgálatok vitatható eredményei és a dronedaron real-world alkalmazása során gyűjtött ellentmondó tapasztalatok igazolták. A 2016-i ESC-AF-ajánlás szerint „ritmuskontroll” (sinusritmus-megtartás) céljából kizárólag anatómiailag ép vagy minimálisan károsodott szívvel bíró, intermittáló AF-ben szenvedő betegeknek rendelhető (azok beleegyezésével, a szimptómák enyhítése és az életminőség javítása, a kórházi kezelések számának csökkentése végett; I osztályú, A-evidenciaszintű ajánlás) (13, 48). A vezérfonal 17. (folyamat) ábráján a panel tagjai a dronedaron-terápiát stabil koszorúér-betegség, klinikailag jelentékeny szívbillentyú-betegség és/vagy balkamra-hipertrófia fennállásakor is ajánlják), noha ezekben a speciális betegcsoportokban (a kétségkívül nagy min- 
taszámú ATHENA-vizsgálattól eltekintve; lásd később) real-world klinikai tapasztalatok elegendő mennyiségben nincsenek $(45,55)$. Emiatt is szembetűnő, hogy a vezérfonal dronedaronnal foglalkozó szövegrészében az utóbb említett vitatható javallatokról már nem esik szó. Nem kívánom nagyobb terjedelemben taglalni az utóbbi években egyre gyakrabban közzétett, tengerentúli és/vagy európai tudományos társaságoktól/szervezetektől delegált szakértőcsoportok által publikált ún. clinical practice guidelines korlátozott megbízhatóságát, ami az írócsoport tagjainak eltérő kvalitású szakmai-tudományos felkészültségével és szubjektív véleményformálásával okolható, a (sokszor igen hathatós) financiális érdekeltségéről, befolyásolásról (deklarált vagy eltitkolt conflict of interest-ről) nem is szólva $(23,45,55)$.

$A z$ amiodaron és a dronedaron szív-elektrofitziológiai hatásait Varró és munkatársai kutyaszívből izolált Purkinje- és munkaizomrostokon, továbbá kamraizomból izolált cardiomyocytákon is összehasonlítoták (84). Kimutatták, hogy az amiodaron az akciós potenciál gyors felszálló szárának sebességét $\left(\mathrm{V}_{\max }\right)$ annál erősebben gátolja, minél nagyobb a frekvencia (84). Fontos különbség az amiodaron és a jódmentes kongéner között, hogy a krónikus per os amiodaron kezelésnek kamraizomsejtekben (50 mg//ttkg/nap négy hétig adagolva) erős „use”-dependens $V_{\max }$-gátló effektusa van; a dronedaron $(2 \times 25 \mathrm{mg} / \mathrm{ttkg} / \mathrm{nap} 4$ héten $\mathrm{ke}$ resztül) $V_{\max }$-gátló hatása gyenge $(5,6,84)$. Burashnikov és munkatársai kimutatták, hogy a krónikus amiodaron-adagolásnak pitvarizomban is van „use" (frekvencia)-dependens" $V_{\max }$-gátló hatása (6), következésképpen az ingerületvezetés sebességét nagy szívfrekvencia-tartományban (pl. AF alatt) erősebben csökkenti, mint normális frekvenciánál. Másfelől, a dronedaron frekvencia-dependens $\mathrm{Na}^{+}$-csatorna $\left(\mathrm{V}_{\max }\right)$ gátló hatása az amiodaronénál sokkal gyengébb ( 6 , 84, 86). Hasonló frekvenciafüggő („use-dependent”) $\mathrm{Na}^{+}$-csatornagátló hatást mind ez ideig csupán két új „atrioszelektív” antiaritmikum, a ranolazin és a vernakalant elektrofiziológiai analízise során tudtak kimutatni $(2,69)$. Fontos preklinikai megfigyelés volt, hogy a krónikus amiodaron kezelés éber kutyában erőteljesen megnyújtja a QT $\mathrm{C}_{\mathrm{c}}$-intervallumot, az állatok szívéből izolált papilláris izomsejtekben pedig erőteljes APD-megnyúlást idéz elő; $\mathrm{QT}_{\mathrm{c}}$ - és APD-prolongációt kiváltó hatása a dronedaronnak nincsen (84). Varró és munkatársai a két gyógyszer összehasonlító vizsgálati eredményeit összegezve megállapították, hogy az idült dronedaron adagolás nem fejt ki a krónikus amiodaron kezelés hatására előálló jótékony elektrofiziológiai effektusokat (84). Burashnikov és munkatársai a koronáriarendszeren keresztül Tyrode-oldattal perfundált pitvari szívizomkészítményekben hasonlították össze az amiodaron és a dronedaron (acetilkolinnal indukált) AF-et megelőző és megszüntető hatását, s a jódmentes kongéner hatásait (számos paramétert mérve) sokkal gyengébbnek találták az anyavegyületnél (5).
Hasonló következtetésre jutott a klinikailag releváns kutyamodellen dolgozó maastrichti munkacsoport, amely in situ kísérletben, teljes AV-blokkban és CHF-ben szenvedő állatokon hasonlította össze a két gyógyszert (amiodaron $\mathrm{n}=7,40 \mathrm{mg} / \mathrm{ttkg} /$ die; dronedaron $\mathrm{n}=8,2 \times 20$ $\mathrm{mg} / \mathrm{ttkg}$; mindkettő hat héten át per os bevíve). Vizsgálataikat teljes atrioventricularis blokk előzetes katéterabláció létrehozása után 6-10 héttel végezték és mindkét szívkamra endokardiális felszínéről monofázisos akciós potenciálokat (MAP) vezettek el az APD és az interventricularis repolarizációs diszperzió $(\triangle A P D=$ balkamra APD mínusz jobbkamrai APD) meghatározása végett. Azt találták, hogy éber állapotban mindkét gyógyszer megnyújtja a $\mathrm{QT}_{\mathrm{c}}$-t, de a kamrai repolarizáció inhomogenitását csak az amiodaron csökkenti, a dronedaron növeli (79). A dronedaron csoportban (éppen a legnagyobb repolarizációs diszparitással bíró) négy állatban torsades de pointes VT (hosszú $\Delta$ [delta] APD) lépett fel (4/8), ezzel szemben az amiodaron csoportban „szerzett hosszú QT-szindrómára” jellemtő proaritmiát egy állatban sem észleltek (0/7). Azt is megfigyelték, hogy a dronedaron sokkal gyakrabban váltott ki VES-t indukáló korai utódepolarizációt (early afterdepolarizations=EADs), mint az amiodaron (79).

Ezek a viszonylag korán (2001-ben) publikált (sokaktól ignorált és/vagy nem idézett) preklinikai vizsgálatok alátámasztották, hogy a két gyógyszer elektrofiziológiai tulajdonságai in vitro és in vivo körülmények között egyaránt különbözőek, másként szólva, a dronedaron nem "jódmentes amiodaron".

Az amiodaronnak nem kompetitív $\alpha$ - és $\beta_{1}$-antiadrenerg (szipatolitikus) tulajdonsága van: gátolja a $\beta$-receptor-aktiválta adenilciklázt, és a krónikus kezelés $\beta$-receptor-downregulációt idéz elő. $\alpha$-és $\beta_{1}$-receptorgátló akitivitása a dronedaronnak is van, de az amiodaronénál sokkal gyengébb (86). Kombinált dronedaron+metoprolol kezelés során (mivel mindkét gyógyszert a citokróm [CYP450] enzimrendszer egyik izoenzimje [a CYP2D6] metabolizálja), a metoprolol negatív dromotrop és inotrop hatása felerősödhet, s ugyanez igaz a nem dihidropiridin $\mathrm{Ca}^{2+}$-antagonistákra (verapamil, diltiazem) is $(30,86)$. Az amiodaron antifibrilláns aktivitása a pitvarokban és a kamrákban egyaránt érvényesül: a tartós orális amiodaron-kezelés növeli az AF transthoracalis elektromos cardioversiójának hatásfokát (4), iv. bevíve pedig növeli a VF defibrillációjának sikerarányát (ARREST=Amiodarone for resuscitation after out-of-hospital cardiac aRREST due to ventricular fibrillation; ALIVE=Amiodarone versus Lidocaine in prehospital Ventricular fibrillation Evaluation). Izolált szívizomsejteken végzett patch clamp mérések szerint az amiodaron APD-t megnyújtó hatásának hátterében a repolarizáló $\mathrm{K}^{+}$-áramok $\left(\mathrm{I}_{\mathrm{Kr}}, \mathrm{I}_{\mathrm{Ks}}, \mathrm{I}_{\mathrm{K}, \mathrm{ACh}}, \mathrm{I}_{\mathrm{K}, \mathrm{ATP}}, \mathrm{I}_{\mathrm{Kur}}\right)$ gátlása áll $(84,86)$. Az utóbbi években bebizonyosodott, hogy a vagustónus-fokozódás és a pitvarsejtek kolinerg-receptorainak izgalma fontos szerepet játszik az AF fellépésében és fennmaradásában: a pitvarspecifikus 
acetilkolin-függő $\mathrm{K}^{+}$-csatorna/áram $\left(\mathrm{I}_{\mathrm{K}, \mathrm{ACh}}\right)$ megnyílása rövidíti az APD-t és az ERP-t. A paraszimpatikus idegvégződésekből fölszabaduló acetilkolin (ACh) moikardiális töménységének változékonyága növeli a pitvari repolarizáció (fiziológiásan is meglévő) spatiotemporalis heterogenitását. Az amiodaron gátolja ezt a (kizárólag a pitvarizomzatban jelenlévő) $\mathrm{K}^{+}$-áramot. Az atrioszelektív és pitvarspecifikus (kizárólag a pitvarsejtekben jelenlévő ioncsatornákra: $I_{\text {KACh }}, I_{\text {Kur }}$ ), ható ntiaritmikumok farmakológiai gátlása új, reménykeltő farmakoterápiás kutatási irányzat $(2,57,69)$. A dronedaron kamrai antifibrilláns és/vagy elektromos defibrillációt facilitáló hatásáról mind ez ideig nem jelent meg közlemény.

Az amiodaron elhanyagolhatóan kicsi proaritmiás aktivitásában az I/B típusú $\mathrm{Na}^{+}$-csatornagátláson kívül szerepet játszik az L-típusú $\mathrm{Ca}^{2+}$-csatornák gátlása, a $\mathrm{Ca}^{2+}$-antagonizmus (30). Gátolja a lassú $\mathrm{Ca}^{2+}$-beáramlást $\left(\mathrm{I}_{\mathrm{Ca}, \mathrm{L}}\right)$, s ha az APD megnyúlik, megelőzi a Ca-csatornák korai utódepolarizáció (early afterdepolarization=EAD) képződést előmozdító reakivációját a repolarizávió II. vagy III. szakaszában való újbóli kinyílását. Nagyobb dózisban bevíve, koncentráció függő módon a dronedaronnak (2×400 mg, étkezés közben, a nausea, hányás és hasmenés előfordulását csökkentendő) $(67,78)$ is van L-típusú $\mathrm{Ca}^{2+}$-beáramlást-gátló tulajdonsága $(67,68)$, ami abból a szempontból előnyös, hogy mérsékel(het)i a drondaron által gyakran kiváltott hasmenést (68). Az amiodaron aktív metabolitja, az N-dezetil-amiodaron (DEA) mindkét kardiális pajzsmirigyhormon-receptor altípus (TR $\alpha 1$, TRß1) in vivo antagonistája, így, a $\beta$-adrenerg-receptortól stimulált adenilcikláz gátlásával karöltve, közvetett módon $\mathrm{K}^{+}$-csatorna-downregulációt eredményez. Az amiodaron gátolja az akut szívizom-iszkémia során aktiválódó, aritmogén lipidközti termékeket (szabad zsírsavakat, lizofoszfoglicerideket) (31) fölszabadító foszfolipáz $A_{2}-t$ és az ilyenkor szintén megnyíló ATP-függő $\mathrm{K}^{+}$-csatornákat $\left(I_{K, A T P}\right)$ is. $E$ hatások összessége minden bizonynyal hozzájárul a heveny myocardium-iszkémia előidézte tachyarrhythmiák megelőzéséhez. Az amiodaron In vivo antioxidáns, s a pitvarizomzat tachycardia indukálta elektromos és strukturális átépülését (az ún. pitvari remodellinget) is csökkenti.

Az amiodaron alkalmazásának határt szab a nemkívánatos extrakardiális mellékhatások viszonylag gyakori előfordulási gyakorisága $(15,85)$. A betegek 5-15\%ában manifeszt hyper- vagy hypothyreosist idéz elö, s a szubklinikai pajzsmirigy-diszfunkció gyakorisága (a 2007-ben publikált SAFE-T-alvizsgálat szerint) még ennél is nagyobb, $\approx 25 \%$. A hosszú felezési idejü (3060 nap), lipofil (a szervezetben felhalmozódó és abból csak hónapok alatt kiürülő), sok jódot tartalmazó foszfolipázgátló gyógyszer a tüdőben lizoszomális foszfolipid-thesaurismosist, alveolitist/pneumonitist és/vagy interstitialis tüdőfibrosist okoz, amely a gyógyszer adagolásának felfüggesztése és (lassú) ürülése közben bevezetett glükokortikoid-kezelésre általában jól rea- gál, de előfordulnak légzési elégtelenséggel szövődő esetek is. A jódmentes dronedaron is antagonizálja a pajzsmirigyhormon TRalfa1-hez való kötődését és az amiodaronnál erősebben bénítja a tüdő-alveolusok makrofág sejtjeit, ezért, az anyavegyülethez hasonlóan, alveolitist/pneumonitist és interstitialis tüdőfibrosist okozhat (86). Megállapítható tehát, hogy a tüdő-toxicitásért nem kizárólag a jód felelős. Az „amiodaron-hepatopathia" ritkán súlyos és/vagy végzetes; e tekintetben a dronedaronhoz hasonlít, amely szintén hepatotoxikus. Eleddig két szervátültetést igénylő, dronedaron okozta akut májelégtelenségről számoltak be.

\section{Dronedaron}

A jódmentes félszintetikus amiodaron-származékokat, mint amilyen a dronedaron (Multaq ${ }^{\mathrm{TM}}$ ), , azzal a céllal fejlesztették ki, hogy a multichannel „anyavegyülethez” hasonló hatáserősségü, de a nagy jódtartalom okozta extrakardiális/toxikus mellékhatásoktól mentes antiaritmiás gyógyszert hozzanak létre $(20,24,41,42)$. A jódatomok eltávolításától a szervtoxicitás megszünését remélték, a metánszulfonamid-csoport hozzáadásával pedig a gyógyszermolekula lipofíliáját mérsékelték. A dronedaron eliminációs féléletideje cca. 24-31 óra, ezért 4-6 nap alatt kiürül a szervezetből. Biológiai hasznosulása az extenzív hepatikus first-pass metabolizmus miatt 15\% (86). Gyógyszer+gyógyszer-interakció miatt simvastatinnal, kumarinokkal, új típusú orális antikoagulánsokkal (NOAC=Novel Oral AntiCoagulants: dabigatran, rivaroxaban, apixaban), antiepileptikumokkal, antidepresszívumokkal, orális azoltípusú antimycoticumokkal nem kombinálható $(14,44)$. A kumarinizációt elsősorban a dronedaron sokszor erős hasmenést kiváltó hatása teszi bizonytalanná (INR-fluktuációt okoz), a trombin- és Xa-faktorgátló NOAC vérszintjét pedig azok hepatikus enzimatikus metabolizációját (CYP3A4) gátolva emeli (67). QT-prolongációt kiváltó kardioaktív vagy nem szív-ér rendszerre ható gyógyszerekkel, Vaughan Williams - Singh I-IV. osztályba tartozó antiaritmikumokkal, ketokonazollal, a pszihotrop szerek többségével, makrolid- és kinolon-típusú antibiotikumok-kal, rifampicinnel, grapefruit juice-szal) való kombinációja kockázatos és nem ajánlott. Digitálisszal kombinálva rövidíti az ún. posztrepolarizációs refrakteritást, növeli a myocardium fibrillációhajlamát és az AV-vezetés gátlásával (bradycardia, AV-blokk) életveszélyes kamrai aritmiá(ka)t provokálhat (39). Sokan úgy elmélkednek, hogy a CHF-ben szenvedő betegcsoportokon végzett dronedaron vizsgálatokban (ANDROMEDA, PALLAS; I. később) amiatt észleltek halálozásnövekedést, mert a páciensek jelentős része digoxint is kapott. A dronedaron $\beta$-adrenerg receptorblokkolóval (különösen metoprolollal) kombinálva gyakran okoz excesszív bradycardiát vagy AV-blokkot, ezért együttadásukra csupán a mellékhatások kockázatát 
vállalva, [a dózis(oka)t óvatosan csökkentve] kerülhet sor. A gyógyszer indukálta májkárosodás (DILI=Drug-Induced Liver Injury) egyik leggyakoribb kiváltó oka a világszerte (nálunk is) népszerü amoxicilin+klavulánsav-kombináció (Augmentin ${ }^{\mathrm{TM}}$ és generikumai). A dronedaron ezen antimikróbás gyógyszerrel való kombinálása természetesen növeli a súlyos májkárosodás fellépésének veszélyét (59).

A multicelluláris myocardium-készítményeken és izolált cardiomyocytákon végzett kísérletek eredményei arra utaltak, hogy a "multichannel” (mind a négy Vaughan Williams-Singh-osztályhatással rendelkező) dronedaron heveny és krónikus elektrofarmakológiai tulajdonságai hasonlóak és egyenértéküek lesznek az amiodaronéval, annak extrakardiális/szervtoxikus hatásai nélkül. Mivel nem tartalmaz jódot, remélhettük, hogy sem hypo-, sem hyperthyreosist nem okoz, ez a várakozásunk azonban nem vált valóra: a dronedaron, az amiodaronnál vitathatatlanul sokkal ritkábban, kiválthat manifeszt vagy szubklinikai pajzsmirigy-diszfunkciót. Tüdőkárosító hatása is van.

Az első prospektív sokközpontú. véletlen beválasztásos, kettős vak (placebo-kontrollcsoportos), „dózistitráló" (a gyógyszer optimális napi adagját meghatározó „fázis 2") klinikai kipróbálásra a DAFNE (Dronedarone Atrial Fibrillation study after Electrical Cardioversion) vizsgálatban került sor (78). A DAFNE-ba 199 jó balkamra-funkciójú (LVEF >50\%, átlagos balpitvari átmérőjü=45 mm), (másfajta) antiaritmiás gyógyszerrel vagy elekt-romosan (egyenáramú elektrokardioverzióval) konvertált perzisztens AF-es beteget válogattak be. A követési idő meglehetősen rövid (6 hónap) volt, s a vizsgálat csupán annak megállapítására volt alkalmas, hogy a Multaq ${ }^{\mathrm{TM}}$ optimális napi adagja kétszer 400 mg, az ennél nagyobb dózisokat a betegek nem (főleg az erős hányinger és hasmenés miatt) nem tolerálják. A nagyobb adagok $(2 \times 600,2 \times 800 \mathrm{mg})$ olyan gyakran okoztak türhetetlen gasztrointesztinális hatásokat hogy egyetértés született a tekintetben, hogy a jövőben használható maximális napi adag 2×400 mg (800 $\mathrm{mg} / \mathrm{die}$ ) lehet. Ezután a dronedaront valamennyi klinikai vizsgálatban ezt a dózist alkalmazva tanulmányozták.

A prospektív. internacionális, véletlen beválasztásos, kettős vak, placebo-kontrollcsoportos, jó kamrafunkciójú (átlagos LVEF >59\%/NYHA I-II) paroxizmális/perzisztens AF-ben és/vagy pitvarlebegésben (AFlu) szenvedő betegeket beválogató, rövid (1 év) követési idejü EURIDIS (European Trial in Atrial fibrillation or Flutter Patients Receiving Dronedarone for the Maintenance of Sinus Rhythm) és ADONIS (American-Australian-African Trial with Dronedarone in Atrial fibrillation or Flutter Patients for the Maintenance of Sinus Rhythm) vizsgálatokban a per os dronedaron $(2 \times 400 \mathrm{mg} / \mathrm{die})$ statisztikailag szignifikánsan, klinikailag azonban nem számottevő mértékben nyújtotta meg az első dokumentált AF/AFlu-recidíváig eltelt időt (73). A gyógyszer adagolását SR alatt kezdték és mindkét betegcsopor- tot $($ dronedaron $=828$; placebo $=409)$ transztelefonos EKG-monitorral és hagyományos EKG-val alkalomszerűen ellenőrizték. $A$ két tanulmány eredményeit összesítették: az első dokumentált AF/AFlu kiújulásáig eltelt idő a dronedaronnal kezeltek körében 116 nap, a placebocsoportban 53 nap volt. Egy év után a dronedaronnal kezeltek 64,1\%-ában, a placebocsoportban 75,2\%-ban regisztráltak AF/AFlu-visszatérést (73). Ha a pitvari tachyarrhythmia kiújult, a dronedaront szedőkben jóval kisebb volt az „átvezetett” kamrafrekvencia (102 \pm 25 ütés/perc), mint a placebocsoportban (117 \pm 29$)$. Az eredmények post hoc elemzése fölvetette, hogy a dronedaron ebben a viszonylag kis CV, normális balkamra-funkciójú, rövid ideig (után)követett kohorszban csökkenti a kórházi kezelést igénylö, súlyos panaszokat okozó perzisztens attakok és az iszkémiás szélütés (stroke) gyakoriságát, s a CV-halálozást is csökkenti, ezeket a retrospektív eredményeket azonban joggal kezeltük fenntartásokkal. A dronedaron a kiindulási értékhez hasonlítva 7\%-kal csökkentette a szív(sinus) frekvenciát, és 23 ms-mal megnyújtotta a QT-időt. A gyakori transztelefonos és hagyományos EKG-ellenőrzés dacára korántsem biztos, hogy az ilyen típusú betegekben igen gyakori (10-40\%) tünetmentes (silent)/éjjeli recidívákat is detektálták, de nem kérdőjelezhető meg, hogy a dronedaron minimális mértékben hatásosabb volt a placebónál az SR megtartása és az AF/AFlu-recidíva alatti kamrafrekvencia-csökkentés tekintetében. A dronedaron-csoportban gyakrabban fordult elő (a későbbiekben is megfigyelt) kreatininvérszint-emelkedés, mint a placebóval kezeltekben $(2,4 \%$ vs. $0,2 \%$; $p=0,004)$ (12). A dronedaront szedő betegek csoportjában gyakoribb volt a hyperthyeosis (67/801) (8,4\%), mint a placebocsoportban (56/396; 14,1\%; p=0,002), s a dronedaron nehézlégzést és köhögést is kiváltott, ez a panasz/tünet azonban nem bizonyult a placebóhoz hasonlítva szignifikánsan gyakoribbnak. Háromszor olyan gyakran okozott a dronedaron hasmenést, mint a placebo (59 vs. 20 beteg), és kétszer olyan gyakran észleltek májfunkciós eltérést az aktívan kezeltek körében (108 vs. 55), a különbség azonban statisztikailag nem bizonyult szignifikánsnak (említésre méltó körülmény, hogy az adatbázis végleges biometriai analízisét a gyógyszert előállító Sanofi-Aventis biometriai osztályának munkatársai végezték) (73).

Az EURIDIS/ADONIS-vizsgálat(ok) eredményeit a tanulmányt irányító, véleményformáló (a)ritmológusok lelkesítő előadásokban ismertették/népszerűsítették, noha az eredmények nem mindenki számára voltak meggyőzőek, elsősorban a szerény efficacy és a rövid követési idő(k) miatt.

Mindazonáltal, az EURIDIS/ADINIS kapcsán sokaknak föltűnt, hogy amikor az AF kiújul, a dronedaron számottevő mértékben csökkenti az „átvezetett” kamrafrekvenciát. Ebből a megfigyelésből kiindulva tervezték meg a figyelemkeltő mozaikszóval jelölt, viszonylag kis mintaszámú ( $n=174)$, prospektív, többközpontú, rando- 
mizált, placebo-kontrollcsoportos (dronedaron-terápia: 85 beteg; placebo 89) ERATO (Efficacy and safety of dRonedArone for The cOntrol of ventricular rate during atrial fibrillation) vizsgálatot, amelybe „megtartott” balkamra-funkcióval (NYHA I-II) bíró, permanens/állandósult AF-ben (AF > hat hónap) szenvedő idős (>65 év) szívbetegeket verbuváltak (11). A CHF (NYHA III-IV) kizáró kritérium volt. A követési idő csupán hat hónap. A dronedaron-adagolás már két hét után és a féléves ellenőrző periódus alatt mindvégig szignifikánsan csökkentette a 24 óra alatt (Holter-monitorral) mért átlagos „átvezetett” kamrafrekvenciát ( $\pm 11,7$ ütés/perc), s e hatás fizikai terhelés során tovább nőtt ( $\pm 24,5$ ütés/perc). A szerzőcsoport fél év alatt proaritmiát, szervtoxicitást nem észlelt (11). A vizsgálat értékét jelentős mértékben csökkenti, hogy a dronedaronnal kezelt betegek 29\%-a AV-vezetést gátló nem-dihidropiridin $\mathrm{Ca}^{2+}$-antagonistát, 40\%-a digoxint, 54\%-a- $\beta$-adrenerg-receptor-blokkolót is kapott ( $d, l$-sotalol kivéve). $A$ „,bázisterápia” természetesen a gyógyszer+gyógyszer-interakció következtében, magától értődően, felerősítette a kamrafrekvencia-csökkentő effektust (11).

Az amerikai gyógyszerhatóság erre hivatott panelje az EURIDIS/ADONIS-vizsgálatok eredményeinek ismeretében úgy döntött, hogy a dronedaron morbiditásra és (a valóban kemény vizsgálati végpontnak tekinthető) összhalálozásra kifejtett hatását mérsékelt és súlyos pangásos szívelégtelenségben (NYHA III-IV.) és balkamra-gyengeségben (LVEF <35\%) szenvedő, proaritmiára hajlamosabb, nagy CV-kockázatú betegcsoportban ( $n=627$; átlagos életkor 69 év) is megvizsgáltatja. Az AF nem volt beválogatási kritérium, csupán a pumpagyengeség (safety trial). A prospektív, randomizált, kettős vak, placebokontrollos ANDROMEDA (ANtiarrhythmic Trial with DROnedarone in Moderate-to-severe congestive heart failure Evaluating morbidity DecreAse) tanulmány célja ennek a kérdésnek a megválaszolása volt. A 2002 júniusában megkezdett vizsgálatot egy közbülső biztonsági analízis kapcsán, 627 beteg beválogatása és kezelése után a független Safety and Monitoring Board két hónap után (2003 januárjában) fölfüggesztette, mivel a dronedaron-csoportban az összhalálozás (all-cause mortality) és a CHF roszszabbodására visszavezethető hospitalizációs igény biostatisztilailag szignifikánsan és klinikailag is könnyen észrevehetően növekedett (placebo 40/317, 12,6\% vs. dronedaron 53/310, 17,1\%) (49). A dronedaron a kezelés első heteiben a betegek egy részében 10-15\%-kal növelte a szérum kreatininszintet, ezért akkortájt újra fölvetődött, hogy a halálozásnövekedést a vesefunkció-rosszabbodás okozza, ez a hipotézis azonban a későbbiekben nem igazolódott (49).

A propektív, multicentrikus, placebo-kontrollcsoportos, nagy mintaszámú $(n=4628)$ ATHENA (A placebo controlled Trial to assess the efficacy of dronedarone 400 mg bid for the prevention of CV Hospitalization or death from any cause in patiENts with Atrial fibrillation/atrial flutter) vizsgálatba idős (>70 év), egy vagy több társbántalomban (hipertenzió, strukturális szívbetegség/ koszorúér-betegség/billentyűhiba, cukorbaj, korábbi tranziens cerebralis iszkémiás attak=TIA, károsodott bal kamrai ejekciós frakció (LVEF <45\%-35\%) szenvedő, viszonylag nagy szív-ér rendszeri kockázattal bíró betegeket válogattak be (42). Dronedaront 2301, placebót 2327 páciens kezdett szedni, de a dronedaront a betegek 30,2\%-a idő előtt abbahagyta. A szerzők a nagymérvű diszkontinuációt egyfelől a gasztrointesztinális mellékhatások (hasmenés) gyakoriságával (26\%), másfelől a kipróbálás alatt lévő új gyógyszer hatékonyságának (szubjektív) alulbecsülésével magyarázták. Az átlagos követési idő \pm 21 hónap volt. Az elsődleges végpont az új keletü CV-eseménynek (elsősorban az AF kiújulásának) betudható első hospitalizáció(k) száma, a másodlagos a teljes és szív-ér rendszeri halálozás volt. A friss CV-eseménnyel (AF/AFlu-recidíva, CHF, heveny koszorúér-szindróma, kamrai szívritmuszavar) megokolható hospitalizáció(k) száma 25\%-kal, ( $p<0,001)$, a CV-halálozás 29\%-kal ( $p<0,034)$ csökkent és kisebb számban számláltak a stasztikusok az aktívan kezeltek körében aritmogén/hirtelen halált $(p<0,01)$. A dronedaronnal kezelt betegeknél gyakoribb volt a szignifikáns bradycardia és a QT-intervellum-megnyúlás ( $p<0,001)$. $A$ „kemény” végpontnak tekinthető összhalálozás nem csökkent, de a biostatisztikailag „komponált” ún. közvetett (kompozit) végpont (amelyet a CV-hospitalizáció és a teljes halálozás összegzése alapján kalkuláltaki), igen, 24\%-kal ( $p<0,001)$ (42). Extrakardiális mellékhatást (pajzsmirigy, tüdő-, máj-toxicitást) csak elvétve $(0,3-0,5 \%)$ észleltek.

Az erőteljesen propagált ATHENA-vizsgálat után kibontakozó, sokakban túlzott lelkesedést kiváltó (továbbá a gyógyszert előállító és a projektbe sok pénzt invesztáló gyógyszergyári nyomásgyakorlás és a világméretü promóciós „kampány” eredményeképpen) a Multaq ${ }^{\mathrm{TM}}$ forgalomba hozatalát az amerikai (FDA=Food and Drug Administration) és az európai (EMA=European Medicines Agency) gyógyszerhatóság engedélyezte, miközben több véleményformáló szakértő (észlelvén a dronedaron szerény effektivitását) javasolta az amiodaron és a dronedaron közvetlen, head-to-head összehasonlítását.

A két gyógyszert összehasonlító prospektív, véletlen beválasztásos, kettős vak, párhuzamos csoportos, 23 ország 112 kardiológiai központjának részvételével lefolytatott DIONYSOS-vizsgálatba (Efficacy and Safety of Dronedarone versus Amiodarone for the Maintenance of Sinus Rhythm in Patients with Persistent Atrial Fibrillation) 504, a vizsgálat kezdete előtt amiodaront nem szedő („amiodaron-naív”) túlnyomórészt ( 70\%) perzisztens (spontánul nem szűnő) AF-től sújtott beteget válogattak: 255 a 28 napos telítő periódus után 200 mg/die amiodaront, 249 páciens 800 mg/die dronedaront kapott (52). A primer összetett végpontot az első, EKG-val dokumentált AF-kiújulás (beleértve a 
sikertelen elektrokardioverziót) és a gyógyszerszedés (hatástalanság vagy mellékhatások/intolerancia miatti) gyakoriságának összesítéséből számították ki. A két kohorsz orvos-biológiai jellemzői (baseline characteristics) a vizsgálat kezdetekor nem különböztek. A kezelés átlagos időtartama hét hónap lett, a vizsgálatot folytatni hajlandó betegeket 14 hónapig ellenőrizték. Az efficacy trial-t szakmai-tudományos és etikai okból hét hónap után felfüggesztették, mivel az amiodaron a betegek 63,5\%-ában a dronedaron a páciensek 42\%-ban tudta megelőzmi az első AF-recidívát $(p<0,0001)$. A sikeres egyenáramú (DC) elektromos kardioverzió után fellépó AF-recidíva is gyakoribb volt a dronedaron csoportban, mint az amiodaronnal kezeltekben (36,5\% vs. $24,3 \%)$ (52). A rövidtávú vizsgálat a kétfajta terápia biztonságosságának (safety) összehasonlítására természetesen nem volt alkalmas.

A prospektív, randomizált, kettős vak, placebo-kontrollcsoportos PALLAS (Permanent Atrial Fibrillation Outcome Study Using Dronedarone on Top of Standard Therapy) vizsgálatba 65 évnél idősebb ( \pm 75 év) nagy CV-kockázatú, súlyos szív- és cukorbetegeket $(n=3236)$ válogattak be (9). A páciensek kétharmadának (NYHA II-III 54\%) CHF-je, 69\%-ának két évnél hosszabb ideje fennálló permanens AF-je/AFlu-ja volt. A betegek 88\%-a kamrafrekvencia-csökkentő farmakoterápiában részesült (egyharmaduk digoxint is kapott!), K-vitamin-antagonista véralvadásgátló (kumarin) kezelésben $84 \%$-uk részesült. A primer összetett kimeneteli végpontot (cerebrális vagy szisztémás artériás embolizáció+akut miokardiális infarktus és/vagy CV halál) szignifikánsan és klinikailag számottevően egyaránt több beteg „érte el” a dronedaron-kohorszban (drornedaron 43, placebo 19; $p<0,002)$. Gyakoribb volt a CV (21 vs. $10 ; p=0,04)$ és az aritmogén (13 vs. 4) halálozás a dronedaronnal kezeltekben $(p=00,3)$. Szignifikánsan több stroke lépett fel az aktívan kezelt kohorszban, s a klinikailag legnyugtalanítóbb mozzanat a dronedaronnal kezelt betegek szívelégtelenségének megkettőzödése vagy a már meglévő CHF föltűnő klinikai rosszabbodása volt (43 vs. 24; $p=0,02$ ). A PALLAS-vizsgálat bizonyította, hogy a dronedaron (a placebóval összevetve) nagy $C V$-rizikójú, permanens AF-es populációban növeli a CHF, az artériás embolizáció és a $\mathrm{CV}$ halál előfordulási gyakoriságát, ezért ilyen betegeknek nem adható (9). A PALLAS-tanulmány eredményeinek közzététele után a EMA CHMP-je (Committee for Medicinal Products for Human Use) jelentést tett közzé, amelyben nyomatékosan javasolta a Multaq ${ }^{\mathrm{TM}}$ terápia megszorítását (14). Tette ezt azért is, mert a posztmarketing szakban (fázis 4) számos bejelentés érkezett az amerikai gyógyszerhatósághoz (FDA = Food and Drug Administration) dronedaron okozta májkárosodásról (DILI=Drug-Induced Liver ljury), s két esetben heveny májelégtelenség miatt sürgős szervátültetésre is szükség volt. Kórisméztek nehézlégzéssel és köhögéssel járó interstitialis tüdőbetegséget (alveolitist, pneumoni- tist, fibrosist) és dronedaron indukálta immunológiai betegségeket is (leukocitoklasztikus vasculitist és anafilaktoid angioödémát). A dronedaron nagyon ritkán okoz 1:1 pitvar-kamrai átvezetéssel járó pitvarlebegést (AFlu) és az eddigi tapasztalatok alapján megállapítható, hogy adekvát alkalmazás (QT-megnyúlást okozó gyógyszer hozzáadása nélkül) kamrai proaritmiás (torsadogen) aktivitása sem nagy, pontos/számszerü adataink e tekintetben azonban mind ez ideig nincsenek. Az amiodaron és a dronedaron AF-megelőző hatáserősségének szemtől szembeni összehasonlítására csak a rövidtávú DYONISOS-vizsgálat nyújtott lehetőséget, de több ún. indirekt metaanalízis alátámasztotta, hogy a dronedaron AF-megelőző hatása gyenge és CHF fennállásakor növeli a teljes és CV-halálozást (8, $64,65)$. Az sem elhanyagolható szempont, hogy a sokkal kevésbé hatékony és szűkülő indikációs körrel bíró Multaq $^{\mathrm{TM}}$ összehasonlíthatatlanul drágább, mint a Cordarone $^{\mathrm{TM}}$ (e. g. az Egyesült Királyságban a dronedaron napi adagjának összköltsége 2,25 angol font, az amiodaroné 0,05 £; National Institute for Health and Clinical Exycellence [NICE]-jelentés) (44).

$\mathrm{Az}$ ideális antiaritmikum(ok) kifejlesztésére irányuló, esélyhozó erőfeszítések magától értődően folytatódnak. Egyfelöl, „erőltetett menetben” folytatódik az újabb benzofurán/amiodaron-származékok (celivaron, budiodaron, KB 130015, US 8318800 B2) szintézise, biokémiai és elektrofiziológiai hatásainak kutatása (amelyben, többek között, a Hideg vezette pécsi munkacsapat is részt vesz) (70). A szegedi kardiofarmakológiai intézet egyik fontos kutatási iránya az amiodaron aktív metabilitjának, az N-dezetil-amiodaronnak (DEA) mélyreható elektrofiziológiai jellemzése. A fő cél természetesen az amiodaron hatásosságának megőrzése és a hepato-, tüdő- vagy pajzsmirigy-toxicitás (és a többi, klinikailag kevésbé súlyos mellékhatás) kiiktatása. Az amiodaron „leánya”, a celivaron már a klinikai kipróbálás szakaszában van, az eddig elvégzett placebo-kontrollcsoportos vizsgálatok (MAIA, CORYFEE, ALPHEE, ICARIOS) azonban arról tanúskodnak, hogy az új származék sinusritmust helyreállító és AF-et megelőző hatása, a dronedaronhoz hasonlóan, sokkal gyengébb, mint az anyavegyületé (50). Randomizált tanulmányok (ALPHEE, ICARIOS) bizonyítják, hogy a celivaron az ICD-beültetésben részesített betegek VT/VF-től indukált ICD-intervencióinak a számát sem csökkenti (50). Az eddig taglalt kudarcok dacára, az új típusú (az eddigiekétől eltérő hatásmechanizmusú) gyógyszerjelöltek tervezése, experimentális és/vagy klinikai kipróbálása (az enormis költségek miatt a korábbiaknál kétségtelenül kisebb számban) lankadatlanul folytatódik. A 2015-ben publikált sokközpontú, kettős vak, randomizált, placebo-kontrollcsoportos Safety and Efficacy of Single Oral Doses of Vanorexine for Conversion of Atrial Fibrillation or Flutter of Recent Onset to Normal Sinus Rhythm (COR-ART) klinikai kísérletben a dopamin-transzporter gátló vanorexin ugyanolyan siker- 
aránnyal szüntette meg a friss keletű ( $<7$ nap) AF-et/ AFlu-t, mint az egyenáramú elektromos kardioverzió (12). Az atrioszelektív, „use-depent” $\mathrm{Na}^{+}$-csatorna gátló vernakalant (Kynapid ${ }^{\mathrm{TM}}$ ) iv. befecskedezve $(2-3 \mathrm{mg} /$ ttkg 10 perc alatt) a betegek 60\%-ában megszünteti a friss keletű (<1 hét) AF-et $(22,57)$. Az amiodaron származék budiodaron a PASCAL (Paroxysmal Atrial Fibrillation Study with Continuous Atrial Logging) biztonságosan csökkentette az AF-terhelést, de a gyógyszer fejlesztését és klinikai kipróbálását az amerikai gyártó (ARYx Therapeutics, Fremont, CA) üzleti okokból felfüggesztette.

Újabb, „második esélyt” kínál a dronedaronnak egy eltérő hatásmechanizmusú antiaritmikummal (a lassú/ késői [late/slow inward] $\mathrm{Na}^{+}$-csatornát [Ina+L] gátló, a stabil angina pectoris gyógyszereként már forgalomban ranolazinnal [Ranexa ${ }^{\mathrm{TM}}$ ]) való együttadás (56). Az internacionális, kettős vak, véletlen beválasztásos, paralel, placebo-kontrollcsoportos, 3. fázisú HARMONY-vizsgálat (Combined Ranolazine and Dronedarone in the Management of Paroxysmal Atrial Fibrillation) eredményei jótékony, szinergista hatást sejtetnek: a jól tolerálható kombinált kezelés hatásossága a beültetett, folyamatos ritmuszavar-detekcióra is alkalmas pacemaker segítségével pontosan mérhető volt (68). A gyógyszer-kombináció (a monoterápiás dózisnál kisebb adagokban: dronedaron: 2×225 mg/die, ranolazin $750 \mathrm{mg} /$ die) 59\%-kal csökkentette az AF-,terhelést”, az AF-ben "töltött” idő összességét). A kicsi mintaszám ( $n=134)$, a rövid követési idő (12 hét) és a fajlagosan szelektált betegcsoport (amely három hónapon belül kétüregű programozható szívütemszabályzóval ellátott paroxizmális AF-es páciensekből állt) nem teszi lehetővé, hogy a tanulmány eredményeiből általános érvényű következtetés(ek)re jussunk, de a klinikai kísérlet pozitív eredménye újra fölcsillantotta a reményt (68). A már idézett kanadai szaktekintély, Stanley Nattel, úgy vélekedik, hogy a hozzáértően kombinált antiaritmiás terápia (amelyet természetesen csak szív-elektrofiziológiában és aritmológiában igen jártas szívgyógyász indikálhat és irányíthat), nem kellőképpen kiaknázott kutatási és farmakoterápiás irányzat. Nem kizárt tehát, hogy a jövőben sikerül (kis dózisban bevitt, proaritmiamentes) antiaritmiás gyógyszer-kombinációval (a manapság oly „divatos” kombo-készítmények valamelyikével) megelőzni az évről évre nagyobb prevalenciájú, a betegek 10-40\%-ában tünetmentes, gyakran váratlan iszkémiás szélütést okozó népbetegséget, az AF-et.

\section{Papp Gyula méltatása}

Akik ezen tisztelgő dolgozat laureátjának szakmai-tudományos életpályáját, elfogulatlan világlátását és emberiességét netán nem ismerik, betekintést kaphatnak a tiszteletére és róla írt kitűnő könyvekből (Számvetés; Ráadás), ünnepi folyóirat-különszámokból a vele készí- tett interjúkból, nyilatkozataiból $(74,80,81)$. Megkérdőjelezhetetlen respektusát a Magyar Kardiológusok Társasága (MKT) is sokszor és sokféleképpen kifejezte. Az MKT-nek 1992-1995 között elnöke, 1995-1998 között a Tudományos Bizottság elnöke volt, jelenleg örökös tiszteletbeli elnök. 1993 óta - az MKT tagjai közül évtizedeken át egyedüliként - a Magyar Tudományos Akadémia (MTA) tagja. Nemzetközi társasági tisztségeit, szerkesztőbizottsági és tiszteletbeli tagságait, akadémiai funkcióit, külföldi és hazai kitüntetéseit fölsorolni e helyütt lehetetlen; ez megtörtént és megjelent a nagyhírü szegedi $\mathrm{CV} /$ szív-elektrofiziológiai műhely nemzetközi és hazai reputációját kiválóan és szorgosan őrző tanszéki utódtól, Varró Andrástól szerkesztett könyvekben $(80,81)$. Tíz évvel ezelőtt, Papp Gyula 70. születésnapja alkalmából már volt alkalmunk dolgozatok írásával nagyrabecsülésünket kifejezni a Cardiologia Hungarica 2008. januári különszámának hasábjain. Jómagam abban a szerencsés helyzetben vagyok, hogy csaknem negyven éve, szegediek lévén, közelröl ismerem Papp Gyulát, a tudóst és a magánembert (1. ábra), s felesleges megerősíteni, hogy nem csupán eminens kardio-farmakológus kutatóprofesszor, hanem kimagasló intellektus, ízig-vérig neoreneszánsz, bibliofil íróember. Fontos leszögezni, hogy jóakaratú, nagyvonalú patrónus is, akinek a bennünk és körülöttünk lévő, gyorsan változó világ minden újdonságáról ma, nyolcvanévesen is, van tudomása, bölcs, határozott, pártatlan, etikus, mindig konstruktív, senkit és semmit nem degradáló véleménye. Rendkívül körültekintően ügyel(t) mindig arra, hogy soha senkit ne bántson meg, hangos szó, durva mondat még keserves élethelyzetekben sem hagyta el a száját. Bárki fordul hozzá támogatásért, aki érdemes rá, meg is kapja (20).

A hazai szívgyógyászat kibontakozása és Haynal Imre (1892-1979) klinikaigazgatói és tudományos müködése óta bővelkedett külföldön is respektált, jeles professzorokban, de alighanem vitathatatlan, hogy a modern magyar kardiológiát Papp Gyulának sikerült, elsősorban oxfordi (1968-1969, 1971, 1981) és párizsi (1990) tanulmányútjai után, nemzetközi tudományos és emberi kapcsolatrendszerét tudatosan és fokozatosan bővítve, „bevinni” az európai kardiológiai színtérre. A 70-es években a rá mindig jellemző alapossággal és „oxfordi” angolsággal bírálatokat írt (többek között) az Európai Kardiológiai Társaság (European Society of Cardiology=ESC) folyóirata főszerkesztőjének felkérésére a European Heart Journal-hoz elküldött kéziratokról. A szerkesztőbizottság tagjai felfigyeltek a kitűnő lektori munkára és 1979-ben beválasztották a folyóirat Editorial Board-jába. Ezt a munkát 1984-ig végezte, majd az ESC elnökségi tagja lett (1984-1994). 1984-1988 között az európai szívtársaság tanácsosa, 1988-1992 között pénztárnoka, 1992-1994 között alelnök és az Ösztöndíj Bizottság (Fellowship Committee) elnöke. Ezen 10 éves periódus alatt az ESC-ben ex officio betöltött tisztségeinél és puvoárjánál fogva sokat 
tett a magyar kardiológia felvirágoztatásáért, az MKT helyzetének, megítélésének nemzetközi javításáért és sok más előremutató jótétemény mellett több magyar szívgyógyásznak (többek között Borbola Józsefnek, Varga Albertnek, Merkely Bélának és nekem) tudott komoly súlyú, hosszú távra szóló külföldi tudományos ösztöndíj elnyerését elősegíteni. E sorok írója, már belgyógyász szakorvosként, hét évnyi belgyógyászati osztályon végzett betegellátó munka után, munkahelyi főnöke, Varró Vince (1921-) klinikaigazgató egyetemi tanár és leendő aspiránsvezetőm, Szekeres László, valamint az MTA Tudományos Minősítő Bizottságának (TMB) hozzájárulásával és támogatásával, 1981-1984 között MTA-aspiránsként teljes munkaidőben a szegedi egyetem aritmiakutatásban élenjáró gyógyszertani intézetében dolgozott. Ekkor kerültem szoros munkakapcsolatba a laureáttal, akivel együttműködve elvégeztük (a heveny szívizom-iszkémia során a cardiomyocyták károsodó foszfolipid-membránjaiból felszabaduló) aritmogén lizofoszfatidilkolin (LPC) in vitro elektropatológiai jellemzését (31) és több közös összefoglaló cikket írtunk különböző témakörökben. Ez a három év életpályám rendkívül hasznos és tanulságos időszaka volt, mert részese lehettem Papp Gyula professzor időt nem kímélő, szigorú és perfekcionista kutatói és szakírói munkájának, s a farmakológiai intézetben töltött három év után (1985-ben) nem volt nehéz megszerezni az orvostudomány kandidátusa (MTA/CSc) tudományos fokozatot (16), amelyet később, az új tudományos minősítési rendszer bevezetése után, az egyetem szintén Papp Gyulától elnökölt Doktori és Habilitációs Bizottsága 1996-ban PhD tudományos fokozatként is elismert. Munkakapcsolatunk a klinikára való visszatérésem után sem szakadt meg, azután is számos közös publikációnk jelent meg. Említettem, hogy az ESC pénztárnoka 1998-1992 között Papp Gyula volt, így aztán nem volt túlságosan nagy meglepetés, hogy az ESC Ösztöndíj Bizottsága 1989 tavaszán úgy döntött, hogy egyik kutatói ösztöndíját az akkor még „szocialista” országok valamelyikében dolgozó, klinikai és experimentális kardiológiai tapasztalatokkal bíró („Janus-arcú”), angolul beszélő orvosnak ítéli oda. Az ösztöndíjat természetesen, a posztkommunista országokból elsőként, azért nyerhettem el, mert élveztem az akkortájt éppen az ESC treasurerjeként tevékenykedő Papp Gyula hathathatós támogatását. Mindmáig büszke vagyok, hogy erre addig és a vele végzett munka alapján érdemesnek tartott. Az akkor már világhírü, programozott elektromos szívingerlést (PES) kifejlesztő Hein JJ Wellens (1935-) maastricht-i kardiológiai klinikáját választottam és egy évig, Papp Gyula jóvoltából, Európa vezető szívközpontjában tanulhattam, dolgozhattam (1990-1991). Az Egyesült Államokban is elismert és tisztelt (korábban Baltimore-ban dolgozó) holland klinikaigazgató ajánlására kaptam meg az American Heart Association (AHA) stipendiumát. AZ USA egyik vezető szív-elektrofiziológiai köpontjában, Ralph Lazzara és a
His-köteg-potenciál humán regisztrálásának technikáját kidolgozó Benjamin J Scherlag (1932-) írányításával az oklahomai egyetem (OUHSC=Oklahoma University Health Sciences Center, College of Medicine) kardiológiai osztályán dolgozhattam 14 hónapig (1992-1993). Ezután is számos alkalommal vehettem részt előadóként (a Soros Alapítvány és az oklahomai kardiológiai klinika anyagi támogatásával) élenjáró amerikai konferenciákon. Ben J. Scherlag, a His-elektrográfia atyja, a világ egyik legnagyobb idézettségü kardiológusa (1969-i Circulation-alapcikke minden invazív szív-elektrofiziológiai publikáció obligát citátuma) 1994-ben, amikor a 22. Belgyógyász Világkongresszusnak (ISIM'94) Budapest adott otthont, Magyarországra is ellátogatott, szimpóziumot szerveztünk. Scherlag referátumokat tartott és Szegedre is ellátogatott. Budapesttől, zsinagógáinktól (a Dohány utcaitól és a szegeditől) el volt ragadtatva (pedig az oklahomai sem akármilyen). Hein Wellens professzort pedig 1995-ben (előterjesztésemre) tiszteletbeli dísztagjává fogadta az MKT és azóta is többször eljött Magyarországra tanítani bennünket. Mind e folyamatokat Papp Gyula „dominószerüen” tovagördülő támogatása indította el és vitte előre.

Először 1977-ben, a 8. Kardiológiai Világkongresszuson (ahol az iskolateremtő Szekeres László professzor nagyszerü, 30 perces referátumot tartott, ami a hallgatóságban ülő fiatal belgyógyászt lenyűgözte és inspirálta), egy tokiói séta és beszélgetés közben vetette fel Szekeres professzor a (később megvalósuló) gondolatot, hogy ti. néhány évre menjek át dolgozni a Gyógyszertani Intézetbe, ahol az experimentális aritmológia és szív-elektrofiziológia alapvonalait elsajátíthatom. A Szekeres Lászlótól kezdeményezett, és a tőle és akadémiai nagydoktor társprofesszorától, Papp Gyulától irányított és körültekintően patronált kutatás, valamint a hollandiai, amerikai és svédországi ösztöndíjas évek alatt végzett munka betetőzéseképpen, védhettem meg, viszonylag fiatalon (50), akadémiai nagydoktori értekezésemet (17). Oklahomai fönökeim, Lazzara és Scherlag professzorok jóvoltából (ajánlásukkal és szponzorációjukkal) lettem 1995-ben az 1979-ben alapított Észak-Amerikai Pacemaker és Elektrofiziológiai Társaság (NASPE=North American Society of Pacing and Electrophysiology, jelenleg HRS=Heart Rhythm Society) első (idehaza dolgozó, nem emigrált) magyar törzstagja. Az akadémikus Papp Gyulától, Merkely Béla és Tenczer Jószef professzoroktól, valamint tőlem szerkesztett Klinikai szív-elektrofiziológia és aritmológia c. sokszerzős kézikönyvet az Akadémiai Kiadó kétszer is kiadta (1999-ben és 2009-ben) és mindkét alkalommal megkapta az MTA V. Orvosi Osztályának nívódíját. Időközben Merkely Béla tanszékvezető egyetemi tanár klinikaigazgató professzor lett, s a közelmúltban az ESC alelnökévé is megválasztották. Ennek elősegítéséért ő maga mondott plénum előtt köszönetet Papp Gyulának. Az elmúlt évtizedekre visszatekintve mindenkinek könynyű belátni, hogy a magyar szívgyógyászatot a hazai 


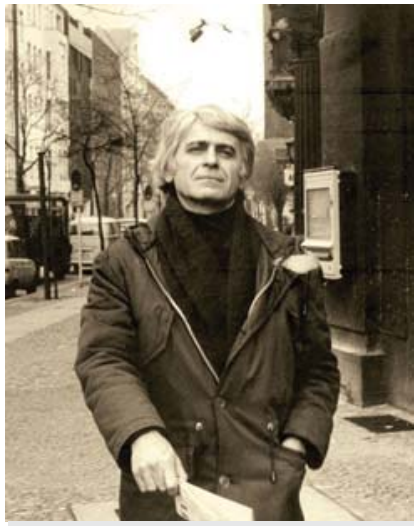

6. ÁBRA. Mészöly Miklós (1921-2001), író, költő és nemzetközi porondon egyaránt fáradhatatlanul támogató Papp Gyulának az egész MKT és közvetlen tanítványai, munkatársai egyaránt nagyon sokat köszönhetnek.

Papp Gyula hazautazásakor, a búcsú során oxfordi mentora, Edward Miles Vaughan Williams a következőket mondta: ,You should keep your mind always open; both mentally and physically you should remain active as long as you can. These are the secrets of a life worth living." Nos, az intracelluláris mikroelektród-technika brit úttörője 98 év és 19 napig élt. Kívánom, hogy tíz esztendő elteltével, 90 éves korában, a mostanihoz hasonló testi-fizikai jólétben és szellemi frissességben köszönthessük újra Papp Gyulát. Írásomat Mészöly Miklós (1921-2001) (6. ábra) derűsen bölcs soraival zárom: „Telik az idő, és nem mi lettünk vénebbek, hanem a sör habja vékonyabb."

\section{Irodalom}

1. Anrep GV, Barsoum GS, Kenaway MR, et al. Ammi visnaga in the treatment of the anginal syndrome. Br Heart J 1946; 8: 171-177. https:// doi.org/10.1016/0002-8703(47)90359-1

2. Antzelevitch C, Burashnikov A. Atrial-selective sodium channe block as a novel strategy for the management of atrial fibrillation. Ann N Y Acad Sci 2010: 1188: 79-86. https://doi.org/10.1111/j.17496632.2009.05086.x

3. Barold SS, Fazekas T. Einthoven's first electrocardiogram 100 years ago. Pacing Clin Electrophysiol 2002; 25: 1792-1793. https://doi.org/ 10.1046/j.1460-9592.2002.01792.x

4. Borbola J. Dronedaron - a következő lépés. Kardiovaszc Rrevenció Rrehab 2010; 3: 29-33.

5. Burashnikov A, Belardinelli A, Antzelevitch C. Acute dronedarone is inferior to amiodarone in terminating and preventing atrial fibrillation in canine atria. Heart Rhythm 2010; 7: 1273-1279. https://doi.org/ 10.1016/j.hrthm.2010.05.019.

6. Burashnikov A, Di Diego JM, Sicouri S, et al. Atrial-selective effects of chronic amiodarone in the management of atrial fibrillation. Heart Rhyt hm 2008; 5: 1735-1742. https://doi.org/10.1016/j.hrthm.2008.09.015

7. Charlier R, Deltour G, Tondeur R, et al. Recherses dans la serie des benzofuranes. VII. Etude pharmacologiue preliminaire du butyl-2(diiodo-3', 5'-beta-N-diethylamino-ethoxy-4'-benzoyl)-3 benzofurane. Arch Intern Pharmacodyn 1962; 139: 255-264

8. Chatterjee S, Ghosh J, Lichstein E, et al. Meta-analysis of cardiovascular outcomes with dronedarone in patients with atrial fibrillation or heart failure. Am J Cardiol 2012; 110: 607-613. https://doi.org/ 10.1016/j.amjcard.2012.04.034

9. Conolly SJ, Camm AJ, Halperin JL, et al for the PALLAS Investigators. Dronedarone in high-risk permanent atrial fibrillation $\mathrm{N}$ Engl Med 2011; 365: 2268-2276. https://doi.org/10.1056/NEJMoa1109867 10. Csanádi Z, Fazekas T, Varró A. A pitvarfibrilláció kezelésének nem farmakológiai lehetöségei. Orv Hetil 2003; 144: 1279-1289.

11. Davy Jm, Herold M, Hoglund C, et al. for the ERATO Investigators. Dronedarone for the control of ventricular rate in permanent atrial fibrillation: and safety of dronedarone for the control of ventricular rate during atrial fibrillation (ERATO). Am Heart J 2008; 156: 527e1-527e9. https://doi.org/10.1016/j.ahj.2008.08.010.12.12.

12. Dittrich HC, Feld GK, Bahnson TD, et al for the COR-ART. A multicenter, randomized, double-blind, placebo-controlled dose-ranging study to evaluate single oral doses of vanoxerine for conversion of re- cent onset atrial fibrillation or flutter to normal sinus rhythm. Heart Rhythm 2015; 12: 1105-1112. https://doi.org/10.1016/j.hrthm.2015.02.014 13. Duray Z, Torp-Pedersen C, Conolly S, et al. Effects of dronedarone on clinical outcomes in patients with lone atrial fibrillation. J Cardiovasc Electrophysiol 2011; 22: 770-776. https://doi.org/10.1111/j.15408167.2010.02006.x

14. European Medicines Agency (EMA) recommends restricting use of Multaq. http://www.ema.europa.eu/ema/index.jsp?_nav=LN\&curl=pages. 2011. September 22.

15. Fazekas T. Az amiodaron. Orvosképzés 1986; 61: 112-123.

16. Fazekas T. Zsírsavak és lizolipidek patogenetikai szerepe a heveny szívizominfarktus korai szakában. Akadémiai (MTA) kandidátusi értekezés/CSc, 1986

17. Fazekas T. Az antiarrhythmiás gyógyszerek klinikai alkalmazásának biztonsága. Antiarrhythmiás és proarrhythmiás gyógyszerhatások. Akadémiai (MTA) (nagy)doktori értekezés/DSc, 2001.

18. Fazekas T. A szívritmuszavarok gyógyszeres kezelésének jelenleg lehetőségei és távlatai. Háziorv Továbbképző Szle 2005; 10: 115-124. 19. Fazekas T. A pitvarremegés áttekintő története. Orvostört Közl 2007; 200-201; 37-68.

20. Fazekas T. Amiodaron — dronedaron? Cardiol Hung 2008; 38(Suppl A): 46-51.

21. Fazekas T. A magyar „szíveskönyvek” kiadástörténete. Cardio Hung 2008; 38: 200-207.

22. Fazekas T, Bogáts G, Csanádi Z, et al. Pitvarfibrilláció. A szívizomsejttöl a betegágyig. Klinikai bizonyítékok. Budapest: Medicina Könyvkiadó; 2010; p. 5-556.

23. Fazekas T. Pitvarlebegés. Budapest: Akadémiai Kiadó; 2013; p. 5-353.

24. Fazekas T. A dronedaron odüsszeája: az antiarrhythmiás gyógyszerfejlesztés sötét fejezete. Magyar Tudományos Akadémia (MTA) Művelödéstörténeti Osztályközi Bizottságának konferenciája; MTA/ Budapest: 2016. június 1

25. Fazekas T, Csanádi Z. A szívritmuszavarok kezelése. Klinikai bizonyítékok. Budapest: Medicina Könyvkiadó; 2004.

26. Fazekas T, Carlsson L, Scherlag BJ, et al. Electrophysiologica and inotropic characterization of a novel Class III antiarrhythmic agent, GLG-V-13, in the mammalian heart. J Cardiovasc Pharmacol 1996; 28: 182-191.

27. Fazekas T, Csanádi Z, Varró A. A pitvarfibrilláció patogenezise és klinikai jelentősége. Orv Hetil 2003; 144: 155-163.

28. Fazekas T, Csanádi Z, Varró A. A pitvarfibrilláció gyógyszeres kezelése. Orv Hetil 2003; 144: 119-1206.

29. Fazekas T, Liszkai G. Az antiarrhythmiás farmakoterápia alapelve az ezredfordulón. Orv Hetil 1999; 140: 2851-2859.

30. Fazekas T, Papp Gy. A kalciumantagonisták klinikai alkalmazásának farmakológiai alapjai. Az orvostudomány aktuális problémái 1989; 63:5-31. 31. Fazekas T, †Németh M, Papp JGy. Cardiac electrophysiological effects of lysolecithin, an ischaemic metabolite, on rabbit atrial and ventricular myocardium. In: Szekeres L, Papp JGy (eds). Pharmacological protection of the myocardium. Vol. 1. Oxford/Budapest: Pergamon Press/Akadémiai Kiadó; 1986. p. 217-222.

32. Fazekas $\mathrm{T}$, Scherlag $\mathrm{Bj}$, Mabo $\mathrm{P}$, et al. Facilitation of reentry by idocaine in canine myocardial infarction. Am Heart J 1994; 127 (2): 345-352. https://doi.org/10.1016/0002-8703(94)90123-6

33. Fazekas T, Smeets J, Wellens HJJ. Az antiaritmiás gyógyszerek aritmogén hatása. A proaritmiák korszerü klinikai szemlélete. Orv Hetil 1991; 132: 2243-2248.

34. Fazekas T, Szabó B, Scherlag BJ. A hosszú QT/QTU-szindróma és a "torsades de pointes” kamrai tachycardia. Orvosképzés 1993; 68: 99-111. 35. Fazekas T, Varró A, Papp Gy. A klinikai arrhythmiák gyógyszeres kezelésének jelenlegi helyzete és perspektívái. Cardiol Hung 1997; 26 $67-77$

36. Fazekas T, Vos Ma, Van Der Zande, et al. Az interventricularis repolarizációs diszperzió-növekedés szerepe az ibutilid által elöidézett monomorf és torsades de pointes kamrai tachycardia kialakulásában. Cardiol Hung 1994; 29: 159-168.

37. Fitzgerald Jd. Class III antiarrhythmic agents: serendipity or drug design? Dialog Cardiovasc Med 2004; 9: 243-252.

38. Franz Mr, Singh SN. Amiodarone and dronedarone: the worker bee and the drone? Heart Rhythm 2010; 7: 1280-1281.

39. Frommeyer G, Milberg G, Grotthof JS, et al. Dronedarone and digitalis: individually reduced post-repolarization refractoriness enhances life-threatening arrhythmias. Europace 2015; 17: 1300-1308. https:// doi.org/10.1093/europace/euu393 
40. Heijman J, Heusch G, Dobrev D. Pleiotropic effects of antiarrhythmic agents: dronedarone in the treatment of atrial fibrillation. Clin Med Insights 2013; 7: 127-140. https://doi.org/10.4137/CMC.S8445

41. Hilleman DE, Mooss AN. Role of dronedarone in atrial fibrillation: more questions than answers. Pharmacotherapy 2010; 30: 867-871. https://doi.org/10.1592/phco.30.9.867

42. Hohnloser SH, Crijns Hjgm, Van Eickels, et al for the ATHENA Investigators. Effect of dronedarone on cardiovascular events in atria fibrillation. N Engl J Med 2009; 360: 688-678. https://doi.org/10.1056/ NEJMoa0803778

43. Hollman A. Plants in cardiology. Amiodarone, nifedipine, sodium cromoglycate. Br Heart J 1991; 65: 57

44. HUGHES S. UK cardiologists petition NICE (National Institute for Health and Clinical Exycellence) to reverse dronedarone decision. The Heartorg 2010. február http://www.theheart.org/article/1045223/print.do 45. Iannone $P$, Haupt $E$, Flego $G$, et al. Dronedarone for atrial fibrillation The limited reliability of clinical practice guidelines. JAMA Intern Med 2014; 174: 625-629. https://doi.org/10.1001/jamainternmed.2013.14485 46. Kathofer $S$, Thomas D, Karle CA. The novel antiarrhythmic drug dronedarone: comparison with amiodarone. Cardiovasc Drug Reviews 2005; 23: 217-230. https://doi.org/10.1111/j.1527-3466.2005.tb00167.x 47. Khitri Ar, Aliot E, Capucci A, et al. Celivarone for maintenance of sinus rhythm and conversion of atrial fibrillation/flutter. J Cardiovasc Electrophysiol 2012; 23: 462-472. https://doi.org/10.1111/j.1540 8167.2011.02234.x

48. Kirchof $P$, Benussi $S$, Kotecha D, at al. Task Force for the management of atrial fibrillation of the European Society of Cardiology (ESC) developed with the special contribution of the European Heart Rhythm Association (EHRA) of the ESC. Endorsed by the European Stroke Organisation (ESO). 2016 ESC Guidelines for the management of atria fibrillation developed in collaboration with EACTS (European Association for Cardio-Thoracic Surgery). Eur Heart J 2016; 37: 2893-2962.

49. Kober L, Torp-Pedersen C. Mcmurray JJ, et al. for the Dronedarone Study Group (ANDROMEDA). Increased mortality after dronedarone for severe heart failure. N Engl J Med 2008; 358: 2678-2687. https:// doi.org/10.1056/NEJMoa0800456

50. Kowey Pr, Crijns Hjgm, Aliot EM, et al. for the ALPHEE Study. Efficacy and safety of celivarone, with amiodarone as calibrator, in patients with an implantable cardioverter-defibrillator for prevention of implantable-cardioverter-defibrillator interventions or death. Circulation 2011 124: 2649-2660. https://doi.org/10.1161/CIRCULATIONAHA.111.072561 51. Laughlin Jc, Kowey PR. Dronedarone: a new treatment for atria fibrillation. J Cardiovasc Elecetrophysiol 2008; 19: 1220-1226. https:// doi.org/10.1111/j.1540-8167.2008.01251.x

52. Le Heuzey JY, DE Ferrari GM, Radzik D, et al. A short-term, randomized, double-blind, parallel-group study to evaluate the efficacy and safety of dronedarone versus amiodarone in patients with persisten atrial fibrillation: the DIONYSOS Study. J Cardiovasc Electrophysio 2010; 21: 597-605. https://doi.org/10.1111/j.1540-8167.2010.01764.x 53. Lengyel Cs, Fazekas T. A szerzett hosszú-QT-szindróma és a torsades de pointes kamrai tachycardia. In: Fazekas T, Merkely B, Papp GY, Tenczer J (szerk). Klinikai szív-elektrofiziológia és aritmológia. Budapest: Akadémiai Kiadó; 2009. p. 673-724.

54. Lengyel CS, Varró A, Tábori K, et al. Combined pharmacologica block of $I_{K_{f}}$ and $I_{K s}$ increases short-term QT interval variability and provokes torsades de pointes. Br J Pharmacol 2007; 151: 941-951. https: doi.org/10.1038/sj.bjp.0707297

55. Mandrola JJ. Dronedarone and clinical guidelines: a dark chapter that must be reread. Medscape 2014; www.medscape.com/viewarticle/820735 print

56. Mullard A. Second chance for dronedarone after recent setback? Lancet 2012; 379: 601. https://doi.org/10.1016/S0140-6736(12)60251-7 57. Muntean DM, Kohajda ZS, Fazekas T, et al. Atrial remodeling in permanent atrial fibrillation: mechanisms and pharmacological implications. J Clin Exp Cardioloq 2013; 11: 2-12. https://doi.org/10.4172/21559880.1000273

58. Nattel S. Dronedarone in atrial fibrillation - Jekyll and Hyde? N Engl J Med 2011; 365: 2321-2322. https://doi.org/10.1056/NEJMe1111997 59. Nainggolan L. FDA drug safety communication: severe liver injury associated with the use of dronedarone (marketed as Multaq). 2011. január 14. http://www.the heart.org/article/1172773/print.do

60. Papp Gy, Csont T, Varró A. Kísérletes szív-ér rendszeri kutatások Szegeden. In: Dux L (szerk). Szegedi Egyetemi Tudástár 4. Élő természettudományok. Szeged: Szegedi Egyetemi Kiadó; 2014. p. 164-188 61. Papp Gy, Németh M, Krassói I, et al. Differential electrophysiologic effects of chronically administered amiodarone on canine Purkinje fibers versus ventricular muscle. J Cardiovasc Pharmacol Therapeut 1996; 1: 287-296

62. Papp Jgy, Straub M, Ziegler D. (eds). Atrial fibrillation: new therapeutic concepts. Solvay Pharmaceutical Conferences. Amsterdam: IOS Press, 2003

63. Papp JGy, Varró A, Végh Á (eds). Achievements of Professor Emeritus László Szekeres. Szeged: Szegedi Tudományegyetem/ Innovariant Nyomdaipari Kft; 2011: p. 7-227.

64. Piccini Jp, Hasselblad V, Peterson ED, et al. Comparative efficacy of dronedarone and amiodarone for the maintenance of sinus rhythm in patients with atrial fibrillation. J Am Coll Cardiol 2009; 54: 1089-1095. 65. Podda GM, Casazza G, Casella F, et al. Addressing the management of atrial fibrillation - a systematic review of the role of dronedarone. Int J Gen Med 2012; 5: 465-478.

66. Reiffel JA. Dronedaron for atrial fibrillation: unbridled enthusiasm or just another small step forward? JAFIB 2009; 1: 500-504

67. Reiffel JA. Dronedarone: where does it fit in the AF therapeutic armamentarium? JAFIB 2013; 5: 157-163.

68. Reiffel JA, Camm AJ, Belardinelli L, et al. and the HARMONY Investigators. The HARMONY trial: combined ranolazine and dronedarone in the management of paroxysmal atrial fibrillation: mechanistic and therapeurtic synergism. Circ Arrhythm Electrophysiol 2015; 8: 1048-1056. 69. Robinson VM, Kowey P. Smoothing the bumpy road to antiarrhythmic drug development. Circulation 2015; 132: 2195-2197.

70. Siddiqui MA, Khan A, Zaka M. A review of structure activity relationship of amiodarone and its derivatives. J Med Chemistry 2016; 6: 37-42.

71. Singh BN, Vaughan Williams EM. The effect of amiodarone, a new anti-anginal drug, on cardiac muscle. Br J Pharmacol 1970; 39: 657-667. 72. Singh D, Cingolani D, Diamond GA, et al. Dronedarone for atria fibrillation. Have we expanded the antiarrhythmic armamentarium? J Am Coll Cardiol 2010; 55: 1569-1576.

73. Singh BN, Conolly SJ, Crijns HJGM, et al. for the EURIDIS AND ADONIS Investigators. Dronedarone for maintenance of sinus rhythm in atrial fibrillation or flutter. N Engl J Med 2007; 357: 987-999.

74. Sulyok E (szerk). In: Aranymosás. Beszélgetések szegedi akadémikusokkal. Papp Gyula: „milyen nagyszerü , milyen kevés és milyen szép - az, ami a lényeg". Szeged: Délmagyarország Könyv-, Lapkiadó és Nyomdaipari Kft; 1995. p. 102-109.

75. SZEKERES L, PAPP JGY. Experimental cardiac arrhythmias and antiarrhythmic drugs. Budapest: Akadémiai Kiadó; 1971. p. 5-448.

76. Szekeres L, Papp JGY. The discovery of antiarrhythmics. Parnham MJ, Bruinvels J (eds). In: Discoveries in pharmacology. Vol 2, chapter 3, part 4: Hemodynamics, Hormones \& inflammation. Amsterdam: Elsevier Science Publishers BV; 1984. p. 185-215.

77. Torp-Pedersen C, Pedersen OD, Kober L. Antiarrhythmic drugs. Safety first. J Am Coll Cardiol 2010; 55: 1577-1579.

78. Touboul P, Brugada J, Capucci, A, et al. Dronedarone for prevention of atrial fibrillation: a dose-ranging study (DAFNE). Eur Heart $J$ 2003; $24:$ 1481-1487.

79. Van Opstal JM, Schoenmakers M, Verduyn C, et al. Chronic amiodarone evokes no torsades de pointes arrhythmias despite QT lengthening in an animal model of acquired long-QT syndrome. Circulation 2001; 104: 2722-2727.

80. Varró A. (szerk). Számvetés. Jubileumi kiadvány Papp Gyula akadémikus tiszteletére. Szeged: Szegedi Tudományegyetem/Innovariant Nyomdaipari Kft: 2007; p. 7-214.

81. Varró A, Baczkó I. (szerk). Ráadás. Nyugállományban is aktívan 2002-2012. A 80 éves Papp Gyula Széchenyi-díjas akadémikus köszöntése. Szeged: Szegedi Tudományegyetem/Innovariant Nyomdaipari Kft; 2017; p. 7-246

82. Varró A, Fazekas T. Az antiarrhythmiás gyógyszerek klinikai alkalmazásának farmakológiai alapjai. Klinikai szív-elektrofiziológia és aritmológia. Fazekas T, Merkely B, Papp Gy, Tenczer J (szerk). Második, átdolgozott kiadás. Budapest: Akadémiai Kiadó; 2009. p. 805-832.

83. Varró A, Fazekas T, Papp GY. Amiodaron - 1994. Cardiol Hung 1995; $24: 5-17$

84. Varró A, Takács J, Németh $M$, et al. Electrophysiological effects of dronedarone (SR 33589), a nonionated amiodarone derivative in the canine heart: comparison with amiodarone. Br J Pharmacol 2001: 133: 625-634. 85. Woosley RL, Singh SN. Arrhythmia treatment and therapy. Evaluation of clinical trial evidence. New York/Basel: Marcel Dekker, Inc. 2000. p. 1-373

86. Zareba KM. Dronedarone: a new antiarrhythmic agent. Drugs Today $2006 ; 42: 75-86$

87. Zimetbaum PJ. Dronedarone for atrial fibrillation - an odyssey. N Engl J Med 2009; 360: 1811-1813 